\title{
Modeling Soil Quality Thresholds to Ecosystem Recovery at Fort Benning, Georgia, USA
}

February 2004

C.T. Garten, Jr., and T.L. Ashwood

Environmental Sciences Division

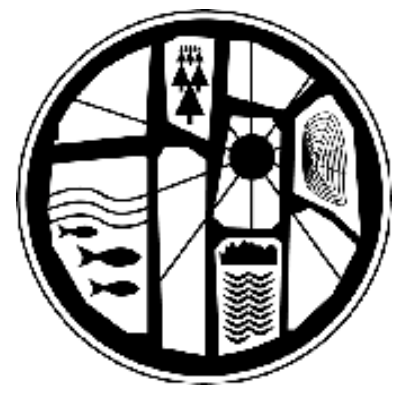




\title{
DOCUMENT AVAILABILITY
}

Reports produced after January 1, 1996, are generally available free via the U.S. Department of Energy (DOE) Information Bridge.

Web site http://www.osti.gov/bridge

Reports produced before January 1, 1996, may be purchased by members of the public from the following source.

\author{
National Technical Information Service \\ 5285 Port Royal Road \\ Springfield, VA 22161 \\ Telephone 703-605-6000 (1-800-553-6847) \\ TDD 703-487-4639 \\ Fax 703-605-6900 \\ E-mail info@ntis.fedworld.gov \\ Web site http://www.ntis.gov/support/ordernowabout.htm
}

Reports are available to DOE employees, DOE contractors, Energy Technology Data

Exchange (ETDE) representatives, and International Nuclear Information System (INIS)

representatives from the following source.

Office of Scientific and Technical Information

P.O. Box 62

Oak Ridge, TN 37831

Telephone 865-576-8401

Fax 865-576-5728

E-mail reports@adonis.osti.gov

Web site http://www.osti.gov/contact.html

This report was prepared as an account of work sponsored by an agency of the United States Government. Neither the United States Government nor any agency thereof, nor any of their employees, makes any warranty, express or implied, or assumes any legal liability or responsibility for the accuracy, completeness, or usefulness of any information, apparatus, product, or process disclosed, or represents that its use would not infringe privately owned rights. Reference herein to any specific commercial product, process, or service by trade name, trademark, manufacturer, or otherwise, does not necessarily constitute or imply its endorsement, recommendation, or favoring by the United States Government or any agency thereof. The views and opinions of authors expressed herein do not necessarily state or reflect those of the United States Government or any agency thereof. 
Environmental Sciences Division

\title{
MODELING SOIL QUALITY THRESHOLDS TO ECOSYSTEM RECOVERY AT FORT BENNING, GEORGIA, USA
}

\author{
C.T. Garten, Jr., and T.L. Ashwood ${ }^{1}$ \\ Environmental Sciences Division \\ Oak Ridge National Laboratory
}

Date Published: February 2004

\author{
Prepared for \\ Strategic Environmental Research and Development Program (SERDP) \\ Ecosystem Management Program (SEMP) \\ Budget Activity Number 4015 ER 010 \\ Prepared by \\ OAK RIDGE NATIONAL LABORATORY \\ Oak Ridge, Tennessee 37831 \\ managed by \\ UT-BATTELLE, LLC \\ for the \\ U.S. DEPARTMENT OF ENERGY \\ under contract DE-AC05-00OR22725
}

${ }^{1}$ Retired 



\section{CONTENTS}

LIST OF FIGURES...............................................................................

LIST OF TABLES................................................................................. vii

ACKNOWLEDGMENTS.......................................................................... ix

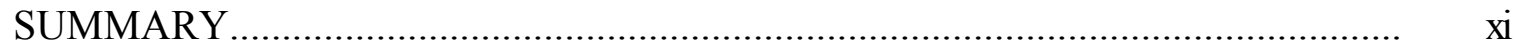

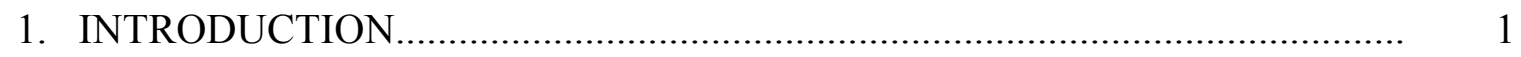

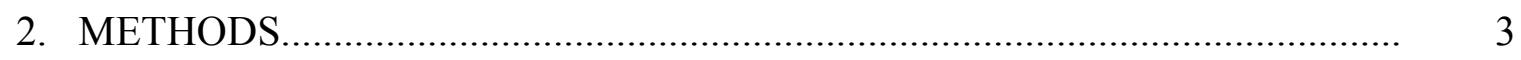

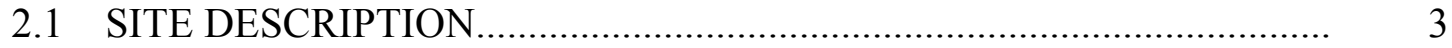

2.2 CONCEPTUAL MODEL ....................................................................... 3

2.3 MODEL EQUATIONS..................................................................... 5

2.3.1 Calculations of Biomass........................................................... 5

2.3.2 Soil Carbon Dynamics.................................................................... 6

2.3.3 Soil Carbon and Nitrogen Stocks..................................................... 6

2.3.4 Biomass Nitrogen Requirement..................................................... 7

2.3.5 Threshold Test............................................................................... 7

2.3.6 Model Parameter Summary........................................................... 8

2.4 FIELD MEASUREMENTS................................................................. 8

2.4.1 Aboveground Biomass................................................................ 8

2.4.2 Soil Carbon and Nitrogen Stocks.................................................. 9

2.4.3 Soil Nitrogen Availability ............................................................. 10

3. RESULTS …..............................................................................................

3.1 MODEL PARAMETERIZATION FROM FIELD DATA..................... 10

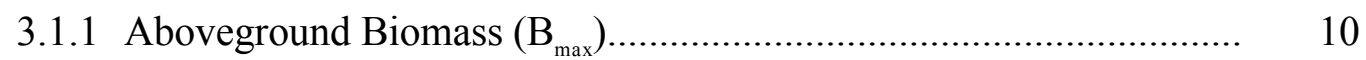

3.1.2 Soil Carbon and Nitrogen Stocks...................................................... 11

3.1.3 Soil Nitrogen Availability............................................................. 12

3.2 MODEL PARAMETERIZATION FROM OTHER SOURCES............. 13

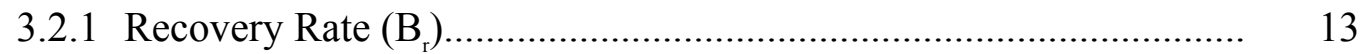

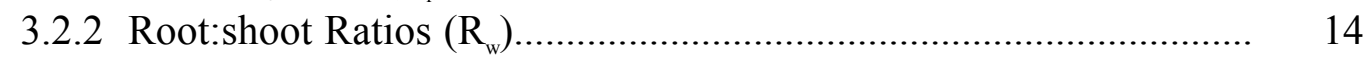

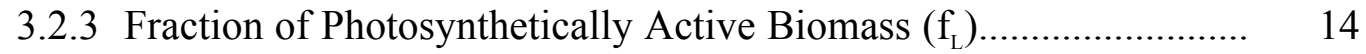

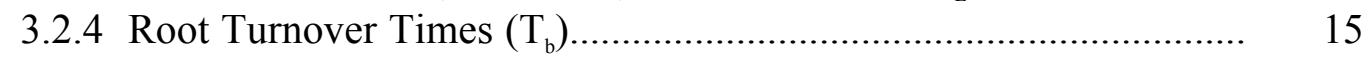

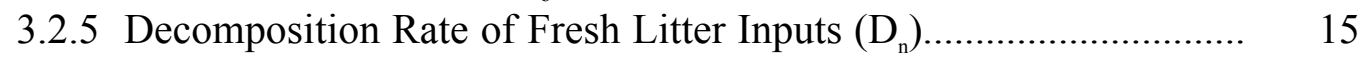

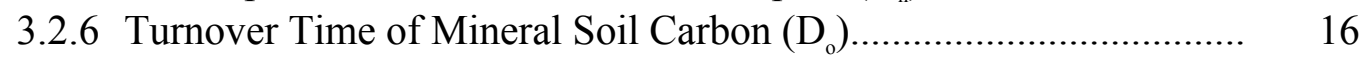

3.2.7 Tissue Carbon and Nitrogen Concentrations.................................. 16

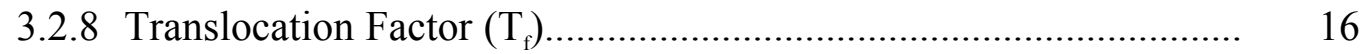

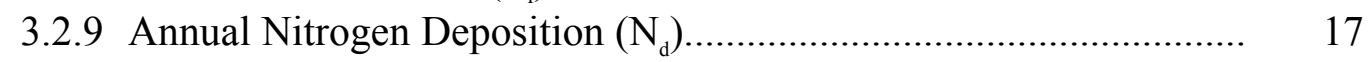

3.3 PREDICTED THRESHOLDS TO RECOVERY .................................. 17 


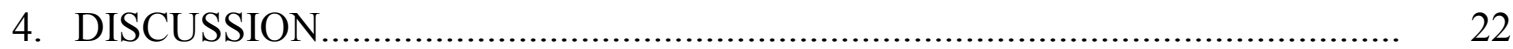

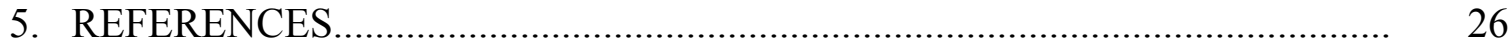




\section{LIST OF FIGURES}

Figure

Page

1 Conceptual model and steps leading up to the nutrient threshold test in the spreadsheet model......

2 Predicted recovery of aboveground biomass density (AGBD) (upper panel), potential excess N (PEN) (middle panel), and soil C stocks (lower panel) for old field development on soils with two different levels of initial soil C stocks at Fort Benning, GA

3 Predicted recovery of aboveground biomass density (AGBD) (upper panel), potential excess N (PEN) (middle panel), and soil C stocks (lower panel) for forest ecosystems with different recovery rates at

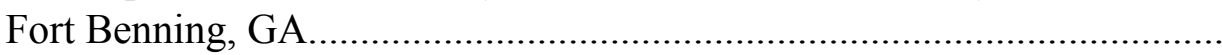

4 Predicted thresholds to recovery for old field and forest ecosystems on more sandy ( $>70 \%$ sand content) and less sandy ( $<70 \%$ sand content) soils at Fort Benning, GA

5 Fraction of surface $(0-20 \mathrm{~cm})$ soil $\mathrm{C}$ associated with particulate organic matter (left panel) and stocks of POM carbon (right panel) in soils with less than (LT) or more than (MT) 70\% sand content under perennial vegetation at Fort Benning, GA.

6 Predicted thresholds to forest recovery (expressed as initial soil C stocks) on more sandy ( $>70 \%$ sand content) and less sandy ( $<70 \%$ sand content) soils as a function of recovery rate $\left(\mathrm{yr}^{-1}\right)$ and percent recovery to a desired future condition (18 $\mathrm{kg}$ aboveground biomass $\mathrm{m}^{-2}$ ). 



\section{LIST OF TABLES}

Table

Page

1 Parameter sets for spreadsheet models of old field and forest soil C and $\mathrm{N}$ dynamics

2 Mineral soil $\mathrm{C}$ and $\mathrm{N}$ stocks, soil $\mathrm{C}: \mathrm{N}$ ratios, extractable inorganic soil $\mathrm{N}$, net $\mathrm{N}$ and $\mathrm{NO}_{3}-\mathrm{N}$ production in 12-week aerobic laboratory incubations, and estimated potential net $\mathrm{N}$ mineralization rate for barren soils at Fort Benning, GA

3 Carbon and $\mathrm{N}$ stocks (g element $\mathrm{m}^{-2}$ ) and $\mathrm{C}: \mathrm{N}$ ratios in old field and forest soils with less than ("less sandy") or more than ("more sandy") $70 \%$ sand content at Fort Benning, GA

4 Extractable inorganic soil $\mathrm{N}\left(\mu \mathrm{g} \mathrm{N} \mathrm{g}^{-1}\right.$ soil), net $\mathrm{N}$ and $\mathrm{NO}_{3}-\mathrm{N}$ production in 12-week laboratory incubations ( $\mu \mathrm{g} \mathrm{N} \mathrm{g}^{-1}$ soil), and estimated potential net $\mathrm{N}$ mineralization rate $\left(\% \mathrm{yr}^{-1}\right)$ in old field and forest soils with less than ("less sandy") or more than ("more sandy") 70\% sand content at Fort Benning, GA.

5 Parameter sets for modeling the nutrient threshold to recovery of old field and forest communities on less sandy (less than $70 \%$ sand) and more sandy (more than 70\% sand) soils at Fort Benning, GA 



\section{ACKNOWLEDGMENTS}

This research is part of the SERDP Ecosystem Management Project (SEMP) and was sponsored by the Strategic Environmental Research and Development Program (SERDP) under contract DE-AC05-00OR22725 with Oak Ridge National Laboratory, managed by UT-Battelle, LLC. SERDP is funded by the U.S. Department of Defense, in partnership with the U.S. Department of Energy and the U.S. Environmental Protection Agency. We wish to thank Bonnie $\mathrm{Lu}(\mathrm{ORNL})$ and Deanne Brice (student intern) for their technical contributions to the work. Hal Balbach, U.S. Army Engineer Research and Development Center (ERDC), kindly reviewed the draft manuscript. Finally, we wish to acknowledge the gracious assistance of John Brent, Theresa Davo, and Pete Swiderek (Fort Benning), and Hugh Westbury (host field site coordinator) to the SERDP-SEMP research initiative at Fort Benning, Georgia. 



\section{SUMMARY}

1. The objective of this research was to use a simple model of soil $\mathrm{C}$ and $\mathrm{N}$ dynamics to predict nutrient thresholds to ecosystem recovery on degraded soils at Fort Benning, Georgia, in the southeastern USA. The model calculates aboveground and belowground biomass, soil C inputs and dynamics, soil $\mathrm{N}$ stocks and availability, and plant $\mathrm{N}$ requirements. A threshold is crossed when predicted soil $\mathrm{N}$ supplies fall short of predicted $\mathrm{N}$ required to sustain biomass accrual at a specified recovery rate.

2. Four factors were important to development of thresholds to recovery: (1) initial amounts of aboveground biomass, (2) initial soil C stocks (i.e., soil quality), (3) relative recovery rates of biomass, and (4) soil sand content. Thresholds to ecosystem recovery predicted by the model should not be interpreted independent of a specified recovery rate. Initial soil C stocks influenced the predicted patterns of recovery by both old field and forest ecosystems.

3. Forests and old fields on soils with varying sand content had different predicted thresholds to recovery. Soil C stocks at barren sites on Fort Benning generally lie below predicted thresholds to $100 \%$ recovery of desired future ecosystem conditions defined on the basis of aboveground biomass (18000 versus $360 \mathrm{~g} \mathrm{~m}^{-2}$ for forests and old fields, respectively).

4. Calculations with the model indicated that reestablishment of vegetation on barren sites to a level below the desired future condition is possible at recovery rates used in the model, but the time to $100 \%$ recovery of desired future conditions, without crossing a nutrient threshold, is prolonged by a reduced rate of forest growth.

5. Predicted thresholds to ecosystem recovery were less on soils with more than $70 \%$ sand content. The lower thresholds for old field and forest recovery on more sandy soils are apparently due to higher relative rates of net soil $\mathrm{N}$ mineralization in more sandy soils.

Calculations with the model indicate that a combination of desired future conditions, initial levels of soil quality (defined by soil C stocks), and the rate of biomass accumulation determines the predicted success of ecosystem recovery on disturbed soils.

Keywords: military land use, ecological thresholds, soil carbon, soil nitrogen, soil $\mathrm{N}$ availability, nutrient dynamics, old fields, forests 


\section{INTRODUCTION}

The concept of thresholds has been applied extensively in science, economics, and regulatory law. Although "threshold" has been defined in various ways, it is generally regarded as the point that separates something true from something not true, or the point at which there is a discernible effect or change in behavior in response to a stimulus (Woolf, 1975). In ecology, thresholds have been defined as system discontinuities, which Muradian (2001) recently defined as "sudden change in any property of an ecological system as a consequence of smooth and continuous change in an independent variable." Other researchers have also defined thresholds as a deflection of system response (or an ecological discontinuity) as a consequence of stress -indicating a breakdown in mechanisms regulating ecosystem function (Romme et al., 1998).

Statistical problems associated with the precise quantification of thresholds, have caused some to question the legitimacy of the threshold concept (Slob, 1999), particularly as it might be applied to complex systems, like ecosystems (Van Straalen, 1997).

Many attributes related to the state of ecosystems or ecosystem processes can be described as continuous variables. Recently, there has been an interest in building connections between continuous measures of soil quality (such as soil density or organic matter content) and ecosystem sustainability in both agriculture (Hussain et al., 1999; Lewandowski et al., 1999; Arshad and Martin, 2002) and forestry (Page-Dumroese et al., 2000; Schoenholtz et al., 2000). Studies that have utilized continuous variables to define ecological thresholds have met both success and failure. For example, in pinon-juniper ecosystems, thresholds to soil erosion are related to the extent of ground cover, and erosion and may change dramatically once a threshold in ground cover is crossed (Davenport et al., 1998). On the other hand, Hunter and White (1997), who examined a variety of continuous (and discontinuous) variables, failed to find thresholds that would distinguish when a forest officially becomes "old growth". They were also unable to discern thresholds to forest disturbance. Although the terms can mean different things to different groups of people, "threshold" and "sustainability" seem to be irreversibly linked (Zinck and Farshad, 1995).

Difficulties in identifying and quantifying thresholds using either continuous or discontinuous variables can be attributed to the complexities of natural systems, our limited predictive capabilities in ecology, and the large uncertainties that sometimes surround the quantification of ecosystem properties and processes (Muradian, 2001). There are many unresolved issues surrounding the use of thresholds to predict when a system is sustainable and when it is not sustainable. Page-Dumroese et al. (2000) concluded, based on a study of several indicators of soil quality (i.e., soil C, N, erosion, and cation exchange capacity) in northwestern forests, that generalized thresholds cannot be successfully applied over disparate soil types and that site-specific information is critical to a valid application of thresholds in forest sustainability. In practical terms, the threshold concept requires an ability to ascertain whether the state of a system lies above or below a threshold, or within some acceptable limits that permit sustainability. For example, thresholds for natural resource management can be defined as an upper limit to harvesting individuals and harvests that exceed the limit endanger the 
sustainability of the population (Lande et al., 1997).

The current research addresses thresholds to ecosystem recovery, which may involve either ecosystem restoration or rehabilitation. Restoration returns an ecosystem to a state that is as similar as possible to its native condition. Ultimately, complete restoration depends on thresholds for recruitment, growth, and mortality of different species as well as the roles that environmental factors play as constraints or as boundaries within which restoration can occur. Complex ecosystems, with multiple interacting species, may have a variety of thresholds. In simple ecosystems, with few interacting species, thresholds to restoration may be more similar to those that define the success or failure of ecosystem rehabilitation (i.e., management toward a desired state not necessarily consistent with, and usually more simple than, the historical native condition). However, ecosystem recovery on severely degraded soils is ultimately related to soil quality and, in particular, nutrient availability. In such systems, seed banks or surrounding vegetation that would serve as a source for colonizing species would have little influence on recovery if critical limiting factors associated with soil quality precluded or inhibited plant growth.

Disturbance of soil physical properties and/or soil structure are commonly reported effects associated with the use of heavy machinery in agriculture (Voorhees et al., 1986; Alakukku and Elonen, 1995), forestry (Hatchell et al., 1970), and military training (Iverson et al., 1981; Prose, 1985; Braunack, 1986; Thurow et al., 1993; Milchunas et al., 1999). At Fort Benning, Georgia, field training with tracked vehicles has resulted in an overall loss of soil quality at some training sites (Garten et al., 2003). Barren, heavily disturbed soils at Fort Benning have negligible $\mathrm{O}$-horizons, lower soil $\mathrm{N}$ availability, and lower soil $\mathrm{C}$ and $\mathrm{N}$ stocks than soils subject to minimal military use (Garten and Ashwood, 2004). In some environments, it has been shown that the effects of soil disturbance by military vehicles can persist for decades (e.g., Iverson et al., 1981). This leads to questions about what factors are at work that might prevent or slow ecosystem recovery following soil disturbance and whether thresholds exist between barren land and the reestablishment of perennial vegetation. The revegetation of barren soils represents an extreme case of ecosystem recovery.

The objective of this research was to use simple models of soil $\mathrm{C}$ and $\mathrm{N}$ dynamics to predict thresholds to ecosystem recovery from degraded soils at Fort Benning, Georgia, in the southeastern USA. Although ecosystem rehabilitation can be less complex than restoration, especially if monocultures are used, there are likely to be thresholds associated with soil properties, vegetation characteristics, and land management. Of these thresholds, various aspects of soil quality may be the root cause that determines the success of ecosystem rehabilitation. In particular, soil organic matter and soil $\mathrm{N}$ availability can be of major importance. Many favorable properties associated with organic matter, such as improved soil structure and greater soil nutrient reserves, argue strongly for the adoption of soil organic matter content (or soil organic C) as one critical metric in defining thresholds to soil quality (Sikora et al., 1996; Seybold et al., 1997). Net primary productivity and standing crop biomass, which partly depend on soil $\mathrm{N}$ availability, are associated measures of success in ecosystem 
rehabilitation. However, the rate of ecosystem recovery to a desired future condition and its degree of success is ultimately constrained by aspects of soil quality.

\section{METHODS}

\subsection{SITE DESCRIPTION}

Fort Benning was established by the U.S. military, near Columbus, Georgia, in 1918, and additional land area was added in 1941. The land area at Fort Benning is $\approx 73,600$ ha, and the number of troops onsite ranges between 18,000 and 23,000 annually. Land use prior to acquisition by the U.S. Government was primarily a mixture of agriculture and forestry. Current land cover at the site is $\approx 49 \%$ mixed forest, $25 \%$ deciduous forest, $10 \%$ barren or developed land, $7 \%$ evergreen forest, $6 \%$ herbaceous grasslands, $2 \%$ shrub land, and $1 \%$ water (Jones and Davo, 1997). Mean annual temperature at Fort Benning is $18.3^{\circ} \mathrm{C}$ and mean annual precipitation is $130 \mathrm{~cm}$.

Soils at the site are highly weathered Ultisols, mostly of Coastal Plain origin but with some minor inclusion of alluviums derived from the Piedmont ecological unit to the north. Two dominant Coastal Plain ecological units that cover most of the installation are Sand Hills and Upper Loam Hills. The major soil series associated with the former units are Ailey loamy coarse sand, Cowarts loamy sand, Nankin sandy clay loam, Pelion loamy sand, Troup, Troup loamy fine sand, Vaucluse, and Vaucluse sandy loam. Sands and loamy sands are common on upland sites while sandy loams and sandy clay loams are frequently found in valleys and riparian areas. Further details on the biology, geology, physical setting, and history of Fort Benning are available elsewhere (Jones and Davo, 1997).

\subsection{CONCEPTUAL MODEL}

Wail et al. (1999) have proposed that biogeochemical cycles of $\mathrm{C}$ and $\mathrm{N}$ connect all the abiotic and biotic components of ecosystems to one another in a holistic way. The concept of the nutrient threshold model (Fig. 1) attempts to summarize these connections in as simple a manner a possible. There are several components to the model that couple soil $\mathrm{C}$ and $\mathrm{N}$ dynamics with ecosystem biomass dynamics: (1) calculation of aboveground and belowground biomass and dynamics, (2) calculation of soil $\mathrm{C}$ inputs and soil $\mathrm{C}$ dynamics, (3) calculation of soil $\mathrm{N}$ stocks and availability, and (4) calculation of plant $\mathrm{N}$ requirements. The nutrient threshold test is represented by a single question, "Are soil $\mathrm{N}$ supplies sufficient to meet the $\mathrm{N}$ demands of growing biomass on track to a desired future ecosystem condition?" A threshold is crossed when soil $\mathrm{N}$ supplies are not sufficient to meet the demands of growing biomass and calculations indicate that the desired future condition, measured in terms of biomass, is not attainable at the specified recovery rate due to resource limitation (i.e., soil $\mathrm{N}$ deficiency).

A central concept in the model (Fig. 1) is "desired future condition" because it represents 
the state against which the success of ecosystem recovery is measured. There are countless attributes that can be used as "metrics" to describe a desired future ecosystem condition. In particular, different target values for aboveground biomass can be associated with different desired future ecosystem conditions. Qualitatively, an observer can see that a forest has more aboveground biomass than an herbaceous field. Quantitatively, we can derive statistics on standing crop biomass for different types of ecosystems and use the mean, the median, or the maximum values as targets for ecosystem recovery. Natural variation in the target value for standing crop biomass and/or net primary production (as indicated by confidence limits about the measure of central tendency) can also be evaluated to determine if an ecosystem is within the expected boundaries for a desired future condition.

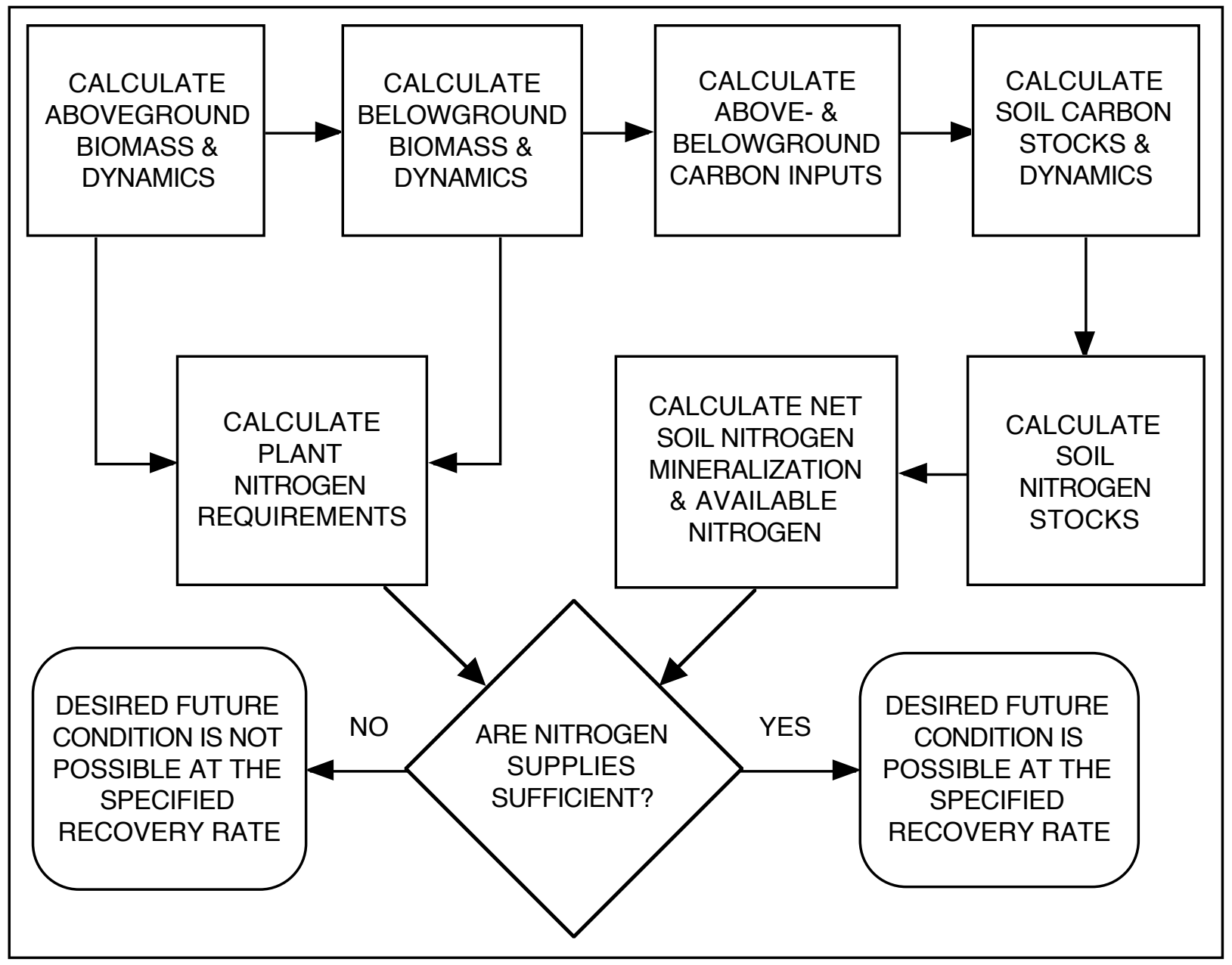

Fig. 1. Conceptual model and steps leading up to the nutrient threshold test in the spreadsheet model. The desired future condition is a target for aboveground standing crop biomass.

The type of resource limiting model described here has been used before, but for different purposes. The model concept is a simplified version of NuCSS (Nutrient Cycling Spreadsheet) 
that simulates, among other things, forest biomass production and soil $\mathrm{N}$ availability (Verburg and Johnson, 2001). NuCSS was developed as a tool for forest nutrient management. Like $\mathrm{NuCSS}$, the model equations were written in a spreadsheet format and they do not include negative feedbacks between soil nutrient supplies and growth of biomass. Incorporation of such feedbacks within the spreadsheet model produces unsolvable circularities in logic. Unlike $\mathrm{NuCSS}$, the model used here does not simulate other element fluxes (including leaching), and has far fewer required model parameters. Although the current model (Fig. 1) is an oversimplification of $\mathrm{C}$ and $\mathrm{N}$ biogeochemistry, the model predictions are potentially useful for guiding military land management decisions.

\subsection{MODEL EQUATIONS}

\subsubsection{Calculations of Biomass}

Relative biomass $(\%)$ over time $(\mathrm{t})$ is calculated from the following equation which yields a logistic growth curve:

$$
\mathrm{B}_{\mathrm{t}}=\mathrm{B}_{\mathrm{t}-1}+\left[\left(\mathrm{B}_{\mathrm{t}-1}\right) *\left(\mathrm{~B}_{\mathrm{r}}\right)\right] *\left[\mathrm{R}-\left(\mathrm{B}_{\mathrm{t}-1}\right) / \mathrm{R}\right]
$$

where $\mathrm{B}_{\mathrm{t}}$ is relative biomass at time $\mathrm{t}(\%), \mathrm{B}_{\mathrm{r}}$ is the fractional growth rate of biomass (per year), and $\mathrm{R}$ is the percent of biomass recovery to the maximum (maximum relative biomass is 100\%). Adjustment of $\mathrm{R}$ allows for the recovery of biomass to some value less than or more than the target (or desired future condition).

Aboveground biomass $\left(\mathrm{B}_{\mathrm{a}}, \mathrm{g} \mathrm{m}^{-2}\right)$ is predicted from:

$$
\mathrm{B}_{\mathrm{a}}=\left(\mathrm{B}_{\mathrm{t}} / 100\right) *\left(\mathrm{~B}_{\max }\right)
$$

where $\mathrm{B}_{\max }$ is the maximum or target aboveground biomass associated with a future desired ecosystem condition (in this case, the maximum biomass and the target biomass are equivalent). Photosynthetically active biomass $\left(B_{f}, g^{-2}\right)$ is predicted from: $B_{f}=B_{a} * f_{L}$, where $f_{L}$ is the fraction of photosynthetically active aboveground biomass (i.e., leaves and green stems).

Belowground biomass $\left(\mathrm{B}_{\mathrm{b}}, \mathrm{g} \mathrm{m}^{-2}\right)$ is predicted from:

$$
\mathrm{B}_{\mathrm{b}}=\mathrm{B}_{\mathrm{a}} * \mathrm{R}_{\mathrm{w}}
$$

where $R_{w}$ is the root:shoot ratio for the ecosystem under consideration. Total biomass $\left(\mathrm{B}_{\mathrm{g}}, \mathrm{g} \mathrm{m}^{-2}\right)$ is predicted from:

$$
\mathrm{B}_{\mathrm{g}}=\mathrm{B}_{\mathrm{a}}+\mathrm{B}_{\mathrm{b}} \text {. }
$$

For old fields, the aboveground biomass growth increment $\left(\Delta \mathrm{B}_{\mathrm{a}}\right)$ and the belowground 
biomass growth increment $\left(\Delta \mathrm{B}_{\mathrm{b}}\right)$ in each year equal, respectively, the aboveground $\left(\mathrm{B}_{\mathrm{a}}\right)$ and belowground $\left(\mathrm{B}_{\mathrm{b}}\right)$ biomass. This assumes that herbaceous old field biomass is replaced every year by new growth following tissue senescence prior to the dormant season. For forests, the aboveground biomass growth increment $\left(\Delta \mathrm{B}_{\mathrm{a}}\right)$ for each year was calculated from:

$$
\Delta \mathrm{B}_{\mathrm{a}}=\mathrm{B}_{\mathrm{a}(\mathrm{t}+1)}-\mathrm{B}_{\mathrm{a}(t)}
$$

The belowground forest biomass growth increment $\left(\Delta \mathrm{B}_{\mathrm{b}}\right)$ for each year was calculated from:

$$
\Delta \mathrm{B}_{\mathrm{b}}=\mathrm{B}_{\mathrm{b}(t+1)}-\mathrm{B}_{\mathrm{b}(t)}
$$

\subsubsection{Soil Carbon Dynamics}

Inputs to soil $\mathrm{C}$ in the model are derived from both aboveground and belowground biomass. Annual belowground root mortality $\left(\mathrm{R}_{\mathrm{m}}, \mathrm{g} \mathrm{m}^{-2}\right)$ is calculated from:

$$
\mathrm{R}_{\mathrm{m}}=\mathrm{B}_{\mathrm{b}} *\left(1 / \mathrm{T}_{\mathrm{b}}\right)
$$

where $T_{b}$ is the turnover time of roots (years).

Annual soil C inputs (I, $\left.\mathrm{g} \mathrm{m}^{-2}\right)$ are calculated from:

$$
\mathrm{I}=\left(\mathrm{B}_{\mathrm{f}} * \mathrm{C}_{\mathrm{b}}\right)+\left(\mathrm{R}_{\mathrm{m}} * \mathrm{C}_{\mathrm{b}}\right)
$$

where $\mathrm{C}_{\mathrm{b}}$ is the $\mathrm{C}$ concentration $\left(\mathrm{g} \mathrm{C} \mathrm{g}^{-1}\right)$ in biomass. The latter equation assumes that photosynthetically active biomass in old fields and forests is returned to the soil each year in seasonal litterfall. Results from other studies (Bray and Gorham, 1964; Sharpe et al., 1980) indicate that evergreen and deciduous forests have comparable annual amounts of aboveground leaf litterfall, therefore no distinction is made here between different forest types.

\subsubsection{Soil Carbon and Nitrogen Stocks}

The predicted soil $\mathrm{C}$ stock depends on the initial conditions for soil $\mathrm{C}\left(\mathrm{S}_{0}\right)$, the decomposition rate, and the calculated $\mathrm{C}$ inputs to soil. The initial soil $\mathrm{C}$ stock is specified at the beginning of the model calculations.

The model tracks both new (i.e., fresh $\mathrm{C}$ inputs) and old soil C. Soil $\mathrm{C}$ stocks at time $\mathrm{t}$ $\left(\mathrm{C}_{\mathrm{t}}, \mathrm{g} \mathrm{C} \mathrm{m}^{-2}\right)$ are calculated from:

$$
\mathrm{C}_{\mathrm{t}}=\mathrm{S}_{\mathrm{t}-1}+\mathrm{I}_{\mathrm{t}}-\left[\left(\mathrm{I}_{\mathrm{t}-1} * \mathrm{D}_{\mathrm{n}}\right)+\left(\mathrm{S}_{\mathrm{t}-1} * \mathrm{D}_{\mathrm{o}}\right)\right]
$$

where, $S_{t-1}$ is the soil C stock at time $t-1, I_{t}$ is the calculated soil C input at time $t, D_{n}$ is the decomposition rate for fresh organic matter inputs $\left(\mathrm{yr}^{-1}\right)$, and $\mathrm{D}_{\mathrm{o}}$ is the decomposition rate $\left(\mathrm{yr}^{-1}\right)$ 
for mineral soil C.

The soil $\mathrm{N}$ stock at time $\mathrm{t}\left(\mathrm{N}_{\mathrm{t}}, \mathrm{g} \mathrm{N} \mathrm{m}^{-2}\right)$ is calculated on the basis of the predicted mineral

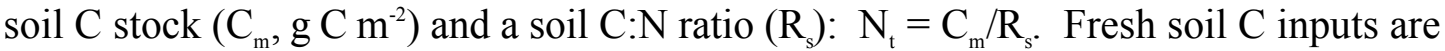
subtracted from $\mathrm{C}_{\mathrm{t}}$ to estimate $\mathrm{C}_{\mathrm{m}}$. It is assumed that the fresh soil $\mathrm{C}$ inputs make no contribution to net soil $\mathrm{N}$ mineralization due to a high $\mathrm{C}: \mathrm{N}$ ratio. Other studies indicate that mineral soil is the primary contributor to soil $\mathrm{N}$ availability whereas new soil $\mathrm{C}$ inputs result primarily in $\mathrm{N}$ immobilization (e.g., Whalen et al., 2000). Annual net soil $\mathrm{N}$ mineralization $\left(\mathrm{N}_{\mathrm{m}}, \mathrm{g}\right.$ $\mathrm{N} \mathrm{m}^{-2}$ ) is calculated from:

$$
\mathrm{N}_{\mathrm{m}}=\mathrm{N}_{\mathrm{t}} * \mathrm{M}_{\mathrm{r}}
$$

where $\mathrm{M}_{\mathrm{r}}$ is the potential annual rate of net soil $\mathrm{N}$ mineralization or, in other words, the fraction of bulk soil $\mathrm{N}$ that is made available for uptake by plant roots through decomposition of soil organic matter.

Total soil $\mathrm{N}$ supplies $\left(\mathrm{N}_{\mathrm{s}}, \mathrm{g} \mathrm{N} \mathrm{m}^{-2}\right)$ for plant nutrition and growth are predicted each year from the following equation:

$$
\mathrm{N}_{\mathrm{s}}=\mathrm{N}_{\mathrm{m}}+\mathrm{N}_{\mathrm{f}}+\mathrm{N}_{\mathrm{d}}
$$

where $\mathrm{N}_{\mathrm{f}}$ is annual $\mathrm{N}$ fertilizer additions to soil $\left(\mathrm{g} \mathrm{N} \mathrm{m}^{-2}\right)$, and $\mathrm{N}_{\mathrm{d}}$ is annual atmospheric $\mathrm{N}$ deposition $\left(\mathrm{g} \mathrm{N} \mathrm{m}^{-2}\right)$.

\subsubsection{Biomass Nitrogen Requirement}

The annual net $\mathrm{N}$ requirement of biomass $\left(\mathrm{B}_{\mathrm{n}}, \mathrm{g} \mathrm{N} \mathrm{m}^{-2}\right)$ is calculated as:

$$
\mathrm{B}_{\mathrm{n}}=\left(\Delta \mathrm{B}_{\mathrm{a}} * \mathrm{~W}_{\mathrm{n}}\right)+\left(\Delta \mathrm{B}_{\mathrm{b}} * \mathrm{R}_{\mathrm{n}}\right)+\left[\left(\mathrm{B}_{\mathrm{f}} * \mathrm{~L}_{\mathrm{n}}\right) *\left(\left(100-\mathrm{T}_{\mathrm{f}}\right) / 100\right)\right]
$$

where $\mathrm{W}_{\mathrm{n}}$ is the $\mathrm{N}$ concentration $\left(\mathrm{g} \mathrm{N} \mathrm{g}^{-1}\right)$ in woody tissues, $\mathrm{R}_{\mathrm{n}}$ is the $\mathrm{N}$ concentration $\left(\mathrm{g} \mathrm{N} \mathrm{g}^{-1}\right)$ in roots, $\mathrm{L}_{\mathrm{n}}$ is the $\mathrm{N}$ concentration in photosynthetically active tissue $\left(\mathrm{g} \mathrm{N} \mathrm{g}^{-1}\right)$, and $\mathrm{T}_{\mathrm{f}}$ is a translocation factor (fraction) that adjusts the $\mathrm{N}$ requirement based on $\mathrm{N}$ reserves that reside within the plant.

\subsubsection{Threshold Test}

Based on predicted biomass and soil $\mathrm{C}$ and $\mathrm{N}$ dynamics, the model calculates the annual $\mathrm{N}$ supply $\left(\mathrm{N}_{\mathrm{s}}, \mathrm{g} \mathrm{N} \mathrm{m}^{-2}\right)$ and subtracts the annual plant $\mathrm{N}$ requirement $\left(\mathrm{B}_{\mathrm{n}}, \mathrm{g} \mathrm{N} \mathrm{m}^{-2}\right)$ to arrive at an estimate of annual potential excess $\mathrm{N}\left(\mathrm{PEN}, \mathrm{g} \mathrm{N} \mathrm{m}^{-2}\right)$. If potential excess $\mathrm{N}$ is negative in any year, then a threshold has been crossed because available soil nutrient resources can not theoretically meet the $\mathrm{N}$ demands of the vegetation on track to a desired future ecosystem condition. If potential excess $\mathrm{N}$ is always positive, then nutrient resources are sufficient to 
achieve the desired future condition as defined by a target aboveground biomass and a specified rate of ecosystem recovery.

\subsubsection{Model Parameter Summary}

The model was parameterized to predict thresholds to recovery for old field and forest ecosystems at Fort Benning, Georgia. Model parameters (Table 1) were derived on the basis of (1) field studies, (2) literature values, and (3) approximation or parameter fitting. Parameters in the latter category included: the recovery rate for aboveground biomass $\left(\mathrm{B}_{\mathrm{r}}\right)$, the decomposition rate of fresh litter inputs $\left(D_{n}\right)$, and wood and root tissue $N$ concentrations $\left(W_{n}\right.$ and $R_{n}$, respectively). Data from the literature were used to set parameter values for root:shoot ratios $\left(R_{w}\right)$, the fraction of photosynthetically active biomass $\left(f_{L}\right)$, root turnover times $\left(T_{b}\right), C$ concentrations in biomass $\left(\mathrm{C}_{\mathrm{b}}\right)$, the turnover time of mineral soil $\mathrm{C}\left(\mathrm{D}_{\mathrm{o}}\right)$, leaf $\mathrm{N}$ concentrations $\left(\mathrm{L}_{\mathrm{n}}\right)$, and $\mathrm{N}$ translocation factors $\left(\mathrm{T}_{\mathrm{f}}\right)$. Field studies at Fort Benning, complemented by data from the literature, were used to establish the following parameter values: targets for aboveground biomass $\left(\mathrm{B}_{\max }\right)$, initial soil $\mathrm{C}$ stocks $\left(\mathrm{S}_{0}\right)$, soil $\mathrm{C}: \mathrm{N}$ ratios $\left(\mathrm{R}_{\mathrm{s}}\right)$, and potential net soil $\mathrm{N}$ mineralization rates $\left(\mathrm{M}_{\mathrm{r}}\right)$. Even though it is included in the model equations, none of the ecosystems that are modeled here receive $\mathrm{N}$ fertilizer.

\subsection{FIELD MEASUREMENTS}

From 1999 to 2002, a variety of field studies were conducted to establish mean values for some soil attributes under different land cover categories at Fort Benning, Georgia. The data set included 14, 18, and 90 sets of measurements from barren sites, old fields, and forest sites, respectively. Sampling sites were widely distributed over the 73,000 ha installation. Details on the sampling methods are published elsewhere (Garten and Ashwood, 2004) but are briefly summarized here for the reader's convenience.

\subsubsection{Aboveground Biomass}

In April, 2002, measurements of diameter at breast height (DBH) were made along $40 \mathrm{~m}$ transects in four relatively undisturbed longleaf pine (Pinus palustris) stands that ranged from 56 to 82 years old. It is possible that the four sites may have been exposed to light military use (i.e., at most, light infantry foot training), but prior studies indicate the effects of such training on measures of soil $\mathrm{C}$ and $\mathrm{N}$ dynamics are not statistically significant (Garten et al., 2003). The basal area was calculated for each stand and converted to estimates of foliar biomass, woody biomass, and total aboveground biomass density $\left(\mathrm{g} \mathrm{m}^{-2}\right)$ using regression equations, specific to longleaf pine, from Mitchell et al. (1999). Along with other estimates of maximum aboveground biomass in forests on the Piedmont (Johnson and Lindberg, 1992) and southeastern Coastal Plain (Switzer et al., 1968), the field data from mature longleaf pine stands were used to parameterize the desired future condition (as defined by aboveground biomass) for forest ecosystems at Fort Benning. Future site management plans include converting approximately half of the installation to longleaf pine forest. 


\begin{tabular}{|c|c|c|}
\hline Parameter (symbol) & Unit & Descrintion (data source) \\
\hline Aboveground biomass $\left(\mathrm{B}_{\max }\right)$ & $\mathrm{g} \mathrm{m}^{-2}$ & $\begin{array}{l}\text { Desired future condition (based on field } \\
\text { data or literature values) }\end{array}$ \\
\hline Recovery (R) & $\%$ & Recovery to maximum biomass \\
\hline Recovery rate $\left(\mathrm{B}_{\mathrm{r}}\right)$ & $\mathrm{yr}^{-1}$ & $\begin{array}{l}\text { Estimated rate of aboveground biomass } \\
\text { accumulation (see text) }\end{array}$ \\
\hline Root:shoot $\left(\mathrm{R}_{\mathrm{w}}\right)$ & ratio & Published sources (see text) \\
\hline Photosynthetically active biomass $\left(f_{L}\right)$ & fraction & Becomes annual leaf litterfall (see text) \\
\hline Root turnover time $\left(\mathrm{T}_{\mathrm{b}}\right)$ & years & From Gill and Jackson (2000) \\
\hline Biomass $\mathrm{C}\left(\mathrm{C}_{\mathrm{b}}\right)$ & $\mathrm{gC} \mathrm{g}^{-1}$ & Various sources (see text) \\
\hline $\begin{array}{l}\text { Decomposition rate of fresh litter } \\
\text { inputs }\left(D_{n}\right)\end{array}$ & $\mathrm{yr}^{-1}$ & $\begin{array}{l}\text { Fitted parameter to yield steady state soil } \\
\text { C stock (see text) }\end{array}$ \\
\hline Turnover time for mineral soil $C\left(D_{\mathrm{o}}\right)$ & years & Derived value (see text) \\
\hline Initial soil $\mathrm{C}$ stock $\left(\mathrm{S}_{0}\right)$ & $\mathrm{g} \mathrm{C} \mathrm{m}^{-2}$ & $\begin{array}{l}\text { Mean value to } 30 \mathrm{~cm} \text { soil depth (from field } \\
\text { data) }\end{array}$ \\
\hline Soil C:N $\left(\mathrm{R}_{\mathrm{s}}\right)$ & ratio & Mineral soil (from field data) \\
\hline Net soil $\mathrm{N}$ mineralization rate $\left(\mathrm{M}_{\mathrm{r}}\right)$ & $\mathrm{yr}^{-1}$ & $\begin{array}{c}\text { Potential rate (estimated from laboratory } \\
\text { incubations) }\end{array}$ \\
\hline Leaf $N\left(L_{n}\right)$ & $\mathrm{g} \mathrm{N} \mathrm{g}^{-1}$ & Various sources (see text) \\
\hline Wood N $\left(\mathrm{W}_{\mathrm{n}}\right)$ & $\mathrm{g} \mathrm{N} \mathrm{g}^{-1}$ & Various sources (see text) \\
\hline Root N $\left(R_{n}\right)$ & $\mathrm{g} \mathrm{N} \mathrm{g}^{-1}$ & Various sources (see text) \\
\hline Translocation factor $\left(\mathrm{T}_{\mathrm{f}}\right)$ & fraction & Estimated internal $\mathrm{N}$ cycling (see text) \\
\hline Annual $\mathrm{N}$ deposition $\left(\mathrm{N}_{\mathrm{d}}\right)$ & $\mathrm{g} \mathrm{N} \mathrm{m}^{-2}$ & Estimated (from NADP/NTN data) \\
\hline Annual $\mathrm{N}$ fertilizer $\left(\mathrm{N}_{\mathrm{f}}\right)$ & $\mathrm{g} \mathrm{N} \mathrm{m}^{-2}$ & None \\
\hline
\end{tabular}

\subsubsection{Soil Carbon and Nitrogen Stocks}

Over a period of three years, soil $\mathrm{C}$ and $\mathrm{N}$ concentrations ( $\mathrm{g}$ element $\mathrm{g}^{-1}$ soil) and stocks ( $\mathrm{g}$ element $\left.\mathrm{m}^{-2}\right)$ were measured at barren sites, old fields, and forests on Fort Benning to a $30 \mathrm{~cm}$ soil depth (Garten and Ashwood, 2004). Replicate soil samples were collected at each site using a stainless steel soil recovery probe $(2.54 \mathrm{~cm}$ inner diameter) with hammer attachment (AMS, American Falls, ID). When present, the O-horizon was removed from a $214 \mathrm{~cm}^{2}$ area directly above each soil sampling point. O-horizon dry mass was determined by drying at $65{ }^{\circ} \mathrm{C}$, and soil samples were air-dried $\left(22^{\circ} \mathrm{C}\right)$ to a constant weight. Air dry soil samples were crushed using a rubber mallet and passed through a $2 \mathrm{~mm}$ sieve. A 20 gram portion of the sieved soil was 
dispersed by shaking overnight in $100 \mathrm{~mL}$ of sodium hexametaphosphate $\left(5 \mathrm{~g} \mathrm{~L}^{-1}\right)$ and the

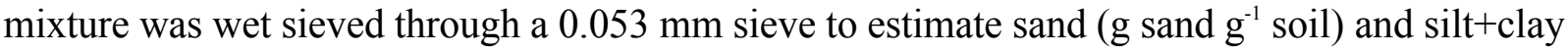
content.

Soil density $\left(\mathrm{g} \mathrm{m}^{-3}\right)$ was estimated from the dry soil mass and the calculated volume of each soil core. O-horizon and mineral soil samples were ground and homogenized and analyzed for $\mathrm{C}$ and $\mathrm{N}$ concentrations using a Perkin-Elmer 2400 Series II CHNS/O Analyzer (Perkin Elmer Analytical Instruments, Norwalk, CT) or a LECO CN-2000 (LECO Corporation, St. Joseph, $\mathrm{MI})$. Carbon and $\mathrm{N}$ stocks in the O-horizon were calculated as the product of concentration ( $\mathrm{g}$ element $\mathrm{g}^{-1}$ dry mass) and dry mass per unit area $\left(\mathrm{g} \mathrm{m}^{-2}\right)$. Soil stocks were calculated as the product of concentration ( $\mathrm{g}$ element $\mathrm{g}^{-1}$ soil), soil density $\left(\mathrm{g} \mathrm{soil} \mathrm{cm}^{-3}\right)$, and sampling depth $(\mathrm{cm})$. The field data were used to parameterize soil C stocks $\left(\mathrm{S}_{0}\right)$ and soil $\mathrm{C}: \mathrm{N}$ ratios $\left(\mathrm{R}_{\mathrm{s}}\right)$ in the model.

\subsubsection{Soil Nitrogen Availability}

Potential net soil $\mathrm{N}$ mineralization was measured in mineral soil (0-20 cm deep) samples using aerobic laboratory incubations (Hart et al., 1994). The fresh mineral soil was passed through a $6.3 \mathrm{~mm}$ sieve to exclude rocks and coarse debris. Using methods described elsewhere (Garten et al., 2003; Garten and Ashwood, 2004), part of the sieved soil was used for the determination of $\mathrm{C}$ stocks in particulate organic matter (POM). A separate portion of sieved soil was extracted by shaking for two hours with 2 molar potassium chloride (1 part soil:10 parts solution) to determine initial extractable soil $\mathrm{NH}_{4}-\mathrm{N}$ and $\mathrm{NO}_{3}-\mathrm{N}$. The sieved soils were incubated in closed plastic jars, in the dark, at room temperature $\left(21^{\circ} \mathrm{C}\right)$. The lids were briefly removed from the jars each week to aerate the soil samples. Extractions of incubating soils were repeated after 12 weeks to determine the net production rate of $\mathrm{NH}_{4}-\mathrm{N}-$ and $\mathrm{NO}_{3}-\mathrm{N}$. Soil extracts were analyzed by digital colorimetry using a Bran+Luebbe AutoAnalyzer 3. Potential net soil $\mathrm{N}$ mineralization was calculated as the difference between extractable inorganic $\mathrm{N}\left(\mathrm{NH}_{4}-\mathrm{N}+\mathrm{NO}_{3}\right.$ $\mathrm{N})$ at 12 weeks and the initial extractable inorganic soil $\mathrm{N}$. The units were $\mu \mathrm{g} \mathrm{N}$ produced $\mathrm{g}^{-1}$ air dry soil based on the moisture content of the initial soil sample. For each sample, net soil $\mathrm{N}$ mineralization ( $\mu \mathrm{g} \mathrm{N}$ produced $\mathrm{g}^{-1}$ soil) over the entire 12-week incubation was normalized for soil $\mathrm{N}$ concentration $\left(\mathrm{g} \mathrm{N} \mathrm{g}^{-1}\right.$ soil) and extrapolated to a potential annual rate (i.e., the fraction of soil $\mathrm{N}$ mineralized each year).

\section{RESULTS}

\subsection{MODEL PARAMETERIZATION FROM FIELD DATA}

\subsubsection{Aboveground Biomass $\left(B_{\max }\right)$}

Estimates of aboveground biomass in longleaf pine stands at Fort Benning were similar to stand biomass in mature (45 year old) forests on the southern Piedmont $\left(\approx 18000 \mathrm{~g} \mathrm{~m}^{-2}\right.$ based on data in Johnson and Lindberg, 1992) and stand biomass in loblolly pine (Pinus taeda) after 50 to 
60 years of stand development $\left(\approx 21000 \mathrm{~g} \mathrm{~m}^{-2}\right.$ based on data in Switzer et al. 1968). Calculated mean $( \pm \mathrm{SE})$ total aboveground biomass in the four longleaf pine stands (ranging from 56 to 82 years old) was $17995 \cdot \pm 2415 \mathrm{~g} \mathrm{~m}^{-2}$. Estimates of foliar and woody biomass in these same stands were $843 \pm 111 \mathrm{~g} \mathrm{~m}^{-2}$ and $17163 \pm 2306 \mathrm{~g} \mathrm{~m}^{-2}$, respectively.

Although old-growth forests in the eastern U.S. may have somewhat greater aboveground biomass densities (22000 to $26000 \mathrm{~g} \mathrm{~m}^{-2}$ based on Brown et al., 1997), the desired future condition for modeling aboveground forest biomass at Fort Benning was set at $18000 \mathrm{~g} \mathrm{~m}^{-2}$. The latter value is in the range of aboveground biomass densities of saw timber stands and forest stands in advanced stages of recovery (after forest clearing) in the eastern U.S. (Brown et al., 1997). Aboveground biomass targets for old field vegetation, $360 \mathrm{~g} \mathrm{~m}^{-2}$, were established on the basis of other studies (Odum, 1960). The selected desired future conditions are merely examples of average recovery targets for the purpose of developing a model to predict thresholds to ecosystem recovery. They do not reflect Fort Benning land management goals that must consider a variety of ecological issues before establishing desired future ecosystem conditions, and which may or may not include maximizing standing biomass.

\subsubsection{Soil Carbon and Nitrogen Stocks}

Sand content in 129 soil samples collected at Fort Benning ranged from 12 to $95 \%$. The mean sand content was $70 \%$ and two-thirds of the samples collected had a sand content that exceeded the mean. For the purpose of further analysis, each soil sample was binned into one of two categories (i.e., "less sandy" or "more sandy") based on whether the sand content was less than or more than $70 \%$.

Barren Sites -- Soils from barren sites, with the exception of one sample, had a sand content greater than $70 \%$ (the exception was $69 \%$ sand). Mineral soil $\mathrm{C}$ and $\mathrm{N}$ stocks at barren sites (Table 2) were significantly less than those measured under old fields and forest cover (Garten and Ashwood, 2004). Because of a lack of plant cover, barren sites were generally devoid of any O-horizon material. Soil C:N ratios at barren sites were highly skewed with an inflated the mean due to a few samples with low soil $\mathrm{N}$ concentrations. The median soil C:N ratio at barren sites was 16.2 and the geometric mean was 22.2 .

Old Fields -- Table 3 summarizes measured $\mathrm{C}$ and $\mathrm{N}$ stocks and $\mathrm{C}: \mathrm{N}$ ratios in the $\mathrm{O}-$ horizon and mineral soil under old fields with less than or more than $70 \%$ sand content. Old fields on less sandy soils had significantly greater soil $\mathrm{C}$ and $\mathrm{N}$ stocks than those on more sandy soils. The more sandy soils also tended to have higher soil $\mathrm{C}: \mathrm{N}$ ratios, but the difference was not statistically significant.

Forests -- Differences in forest soil C stocks under less sandy and more sandy soils were not statistically significant (Table 3 ). Forest O-horizon $\mathrm{N}$ stocks were significantly greater on more sandy soils but the mineral soil $\mathrm{N}$ stocks were significantly lower than those on less sandy sites. Similar to old field sites, forest mineral soil C:N ratios were elevated at sites with more 
than $70 \%$ sand content.

Table 2. Mineral soil $\mathrm{C}$ and $\mathrm{N}$ stocks, soil $\mathrm{C}: \mathrm{N}$ ratios, extractable inorganic soil $\mathrm{N}$, net $\mathrm{N}$ and $\mathrm{NO}_{3}-\mathrm{N}$ production in 12-week aerobic laboratory incubations, and estimated potential net $\mathbf{N}$ mineralization rate for barren soils at Fort Benning, GA

\begin{tabular}{|c|c|c|c|c|c|}
\hline Variable & Units & $\mathrm{n}$ & Mean & SE $^{\mathrm{a}}$ & C.V. $^{{ }^{\mathrm{b}}}$ \\
\hline Soil C stock & $\mathrm{g} \mathrm{C} \mathrm{m}^{-2}$ & 14 & 629 & 146 & 0.87 \\
\hline Soil N stock & $\mathrm{g} \mathrm{N} \mathrm{m}^{-2}$ & 14 & 39.4 & 9.5 & 0.90 \\
\hline Soil C:N ratio & none & 12 & 37.7 & 16.4 & 1.51 \\
\hline Extractable inorganic $\mathrm{N}$ & $\mu \mathrm{g} \mathrm{N} \mathrm{g}^{-1}$ & 14 & 0.97 & 0.20 & 0.76 \\
\hline Net N production & $\mu \mathrm{g} \mathrm{N} \mathrm{g}^{-1}$ & 14 & 1.13 & 0.62 & 2.05 \\
\hline Net $\mathrm{NO}_{3}-\mathrm{N}$ production & $\mu \mathrm{g} \mathrm{N} \mathrm{g}^{-1}$ & 14 & 0.84 & 0.02 & 0.09 \\
\hline Net $\mathrm{N} \mathrm{mineralization} \mathrm{rate}^{2} \mathrm{y}^{-1}$ & 14 & 4.6 & 3.2 & 2.60 \\
\hline $\begin{array}{l}{ }^{\mathrm{a}} \text { Standard error } \\
{ }^{\mathrm{b}} \text { Coefficient of variation }\end{array}$ & & & & \\
\hline
\end{tabular}

\subsubsection{Soil Nitrogen Availability}

Barren sites -- Consistent with lower soil N stocks, there was less soil N availability under barren sites compared to sites occupied by perennial vegetation (Garten and Ashwood, 2004). Absolute amounts of potential net soil $\mathrm{N}$ mineralization and net nitrification in aerobic laboratory incubations were reduced at barren sites (Table 2). However, the potential annual net $\mathrm{N}$ mineralization rate for barren soils was comparable to old field and forest soils.

Old fields -- Differences in $\mathrm{N}$ availability between old fields on less sandy or more sandy soils are presented in Table 4. Compared to more sandy soils, less sandy soils tended to have higher levels of extractable inorganic soil $\mathrm{N}$ (there was a $10 \%$ probability that this difference occurred by chance). Differences between less sandy and more sandy soils in net $\mathrm{N}_{\text {and }} \mathrm{NO}_{3}-\mathrm{N}$ production during the 12 week aerobic laboratory incubations were not statistically significant. The mean potential net $\mathrm{N}$ mineralization rate, expressed on an annual basis, tended to be greater in old field soils with more than $70 \%$ sand content $(P<0.10)$. If not all, most of the soil $\mathrm{N}$ mineralization terminated by production of $\mathrm{NO}_{3}-\mathrm{N}$, a highly available form of soil $\mathrm{N}$.

Forests -- Measures of soil $\mathrm{N}$ availability in forest soils were similar to those for old field soils (Table 4). Based on results from the laboratory incubations, there were no statistically significant differences in $\mathrm{N}$ availability between less sandy and more sandy forest sites.

However, consistent with trends observed for old field soils, the potential $\mathrm{N}$ mineralization rate was greater in forest soils with more than $70 \%$ sand content. As in old field soils, most of the net soil $\mathrm{N}$ mineralization terminated in the production of $\mathrm{NO}_{3}-\mathrm{N}$. 


\begin{tabular}{|c|c|c|c|c|c|c|c|c|}
\hline \multicolumn{9}{|c|}{$\begin{array}{l}\text { Table 3. Carbon and } \mathrm{N} \text { stocks }\left(\mathrm{g} \text { element } \mathrm{m}^{-2} \text { ) and } \mathrm{C}: \mathrm{N} \text { ratios in old field and forest soils }\right. \\
\text { with less than ("less sandy") or more than ("more sandy") } 70 \% \text { sand content at Fort } \\
\text { Benning, GA }\end{array}$} \\
\hline \multirow[b]{2}{*}{ Variable } & \multirow[b]{2}{*}{ Soil part } & \multicolumn{3}{|c|}{ Less sandy } & \multicolumn{3}{|c|}{ More sandy } & \multirow[b]{2}{*}{ F-value } \\
\hline & & $\mathrm{n}$ & Mean & $\mathrm{SE}$ & $\mathrm{n}$ & Mean & $\mathrm{SE}$ & \\
\hline & & \multicolumn{6}{|c|}{ - Old field soils - } & \\
\hline \multirow[t]{3}{*}{ C stock } & O-horizon & 6 & 151 & 82 & 9 & 90 & 25 & 0.7 \\
\hline & Mineral soil $^{\mathrm{a}}$ & 7 & 3457 & 192 & 11 & 2440 & 230 & $9.6 * *$ \\
\hline & Total & 6 & 3702 & 252 & 10 & 2514 & 261 & $9.2 * *$ \\
\hline \multirow[t]{3}{*}{$\mathrm{N}$ stock } & O-horizon & 6 & 5.6 & 4.0 & 9 & 2.2 & 0.7 & 1.1 \\
\hline & Mineral soil $^{\mathrm{a}}$ & 7 & 189 & 33 & 11 & 99 & 15 & $7.7^{*}$ \\
\hline & Total & 6 & 197 & 43 & 10 & 103 & 16 & $6.0^{*}$ \\
\hline \multirow[t]{3}{*}{$\mathrm{C}: \mathrm{N}$} & O-horizon & 3 & 38.9 & 12.8 & 7 & 44.6 & 4.3 & 0.3 \\
\hline & Mineral soil $^{\mathrm{a}}$ & 7 & 21.6 & 3.8 & 11 & 34.6 & 9.0 & 1.2 \\
\hline & & \multicolumn{6}{|c|}{ - Forest soils - } & \\
\hline \multirow[t]{3}{*}{ C stock } & O-horizon & 33 & 378 & 24 & 56 & 450 & 27 & 3.4 \\
\hline & Mineral soil ${ }^{\mathrm{a}}$ & 34 & 3342 & 186 & 56 & 3397 & 211 & 0.0 \\
\hline & Total & 34 & 3709 & 188 & 56 & 3847 & 221 & 0.2 \\
\hline \multirow[t]{3}{*}{$\mathrm{N}$ stock } & O-horizon & 33 & 6.4 & 0.6 & 56 & 8.7 & 0.7 & $5.0^{*}$ \\
\hline & Mineral soil ${ }^{a}$ & 34 & 167 & 11 & 56 & 109 & 6 & $24 * * *$ \\
\hline & Total & 34 & 173 & 12 & 56 & 118 & 6 & $21 * * *$ \\
\hline \multirow[t]{2}{*}{$\mathrm{C}: \mathrm{N}$} & O-horizon & 33 & 66.7 & 4.3 & 56 & 60.9 & 3.6 & 1.0 \\
\hline & Mineral soil ${ }^{\mathrm{a}}$ & 34 & 21.4 & 1.1 & 56 & 35.6 & 3.9 & $7.9 * *$ \\
\hline $\begin{array}{l}{ }^{\mathrm{a}} \text { Depth o } \\
* \mathrm{P} \leq 0.0\end{array}$ & nineral soil $\mathrm{i}$ & & & & & & & \\
\hline
\end{tabular}

\subsection{MODEL PARAMETERIZATION FROM OTHER SOURCES}

Many parameter values (Table 5) in the model were established on the basis of sources other than field data because site-specific data were not available. The rationale for setting parameter values based on other sources is described in the following paragraphs.

\subsubsection{Recovery Rate $\left(B_{r}\right)$}

The recovery (or growth) rate for forest stands was set to $0.15 \mathrm{yr}^{-1}$. At this rate, the stand achieves $95 \%$ of its target desired future condition $\left(18000 \mathrm{~g} \mathrm{~m}^{-2}\right)$ in $\approx 50$ years when starting 
from an initial condition of $360 \mathrm{~g} \mathrm{~m}^{-2}$. The annual recovery rate for herbaceous old fields was set at $1.0 \mathrm{yr}^{-1}$ on the basis that herbaceous communities tend to rapidly achieve a steady state standing biomass from existing soil seed banks and recolonization by opportunistic species. Recovery rates can be adjusted at the discretion of the user for different types of plant communities.

\begin{tabular}{|c|c|c|c|c|c|c|c|}
\hline \multirow{2}{*}{ Variable } & \multicolumn{3}{|c|}{ Less sandy } & \multicolumn{3}{|c|}{ More sandy } & \multirow{2}{*}{ F-value } \\
\hline & $\mathrm{n}$ & Mean & SE & $\mathrm{n}$ & Mean & SE & \\
\hline & \multicolumn{6}{|c|}{ - Old field soils - } & \\
\hline Extractable inorganic $\mathrm{N}$ & 7 & 4.3 & 1.9 & 11 & 1.5 & 0.2 & $3.5^{\mathrm{a}}$ \\
\hline Net $\mathrm{N}$ production & 7 & 4.7 & 3.2 & 11 & 5.4 & 1.3 & 0.0 \\
\hline $\mathrm{Net} \mathrm{NO}_{3}-\mathrm{N}$ production & 7 & 4.5 & 2.3 & 11 & 6.2 & 1.3 & 0.4 \\
\hline \multirow[t]{2}{*}{ Net $\mathrm{N}$ mineralization rate } & 7 & 2.5 & 1.9 & 11 & 7.1 & 1.4 & $4.1^{\mathrm{a}}$ \\
\hline & \multicolumn{6}{|c|}{ - Forest soils - } & \\
\hline Extractable inorganic $\mathrm{N}$ & 34 & 2.6 & 0.3 & 56 & 2.2 & 0.2 & 0.8 \\
\hline Net $\mathrm{N}$ production & 34 & 4.6 & 1.1 & 56 & 5.4 & 1.0 & 2.7 \\
\hline $\mathrm{Net} \mathrm{NO}_{3}-\mathrm{N}$ production & 34 & 3.5 & 1.0 & 56 & 4.3 & 0.9 & 0.4 \\
\hline Net $\mathrm{N}$ mineralization rate & 34 & 2.6 & 0.5 & 56 & 6.4 & 1.1 & $6.9 * *$ \\
\hline $\begin{array}{l}{ }^{\mathrm{a}} \mathrm{P} \leq 0.10 \\
* * \mathrm{P} \leq 0.01\end{array}$ & & & & & & & \\
\hline
\end{tabular}

\subsubsection{Root:shoot Ratios $\left(\mathbf{R}_{\mathrm{w}}\right)$}

The root:shoot ratio in forest stands was set at 0.23 based on information presented by Jackson et al. (1996) and Cairns et al. (1997) who summarized global data on root biomass from terrestrial biomes and upland forests, respectively. The root:shoot ratio under old fields was set to 1.0 based on studies by Kelly (1975) who measured root:shoot ratios of 0.78 and 1.4 in two east Tennessee old field communities.

\subsubsection{Fraction of Photosynthetically Active Biomass $\left(f_{L}\right)$}

This parameter determines the portion of aboveground biomass that contributes to annual soil C inputs. Based on data from forests in the southeastern U.S. (Johnson and Van Hook, 1989; Johnson and Lindberg, 1992), leaf biomass is typically 2 to $5 \%$ of total aboveground biomass. Unlike trees, both stems and leaves are photosynthetically active in many herbaceous 
plants. For the purposes of modeling thresholds to recovery, the fraction of photosynthetically active biomass in forests and herbaceous old fields was set at 3.5\% and 100\%, respectively.

\begin{tabular}{|c|c|c|c|c|c|}
\hline \multirow[b]{2}{*}{ Parameter } & \multirow[b]{2}{*}{ Units } & \multicolumn{2}{|c|}{ Less sandy } & \multicolumn{2}{|c|}{ More sandy } \\
\hline & & Old field & Forest & Old field & Forest \\
\hline $\mathrm{B}_{\max }$ & $\mathrm{g} \mathrm{m}^{-2}$ & 360 & 18000 & 360 & 18000 \\
\hline $\mathrm{R}$ & $\%$ & 100 & 100 & 100 & 100 \\
\hline $\mathrm{B}_{\mathrm{r}}$ & $\mathrm{yr}^{-1}$ & 1.0 & 0.15 & 1.0 & 0.15 \\
\hline $\mathrm{R}_{\mathrm{w}}$ & ratio & 1.0 & 0.23 & 1.0 & 0.23 \\
\hline$f_{L}$ & fraction & 1.0 & 0.035 & 1.0 & 0.035 \\
\hline $\mathrm{T}_{\mathrm{b}}$ & years & 2.0 & 10 & 2.0 & 10 \\
\hline $\mathrm{C}_{\mathrm{b}}$ & $\mathrm{gC}^{-1}$ & 0.45 & 0.45 & 0.45 & 0.45 \\
\hline$D_{n}$ & $\mathrm{yr}^{-1}$ & 0.8982 & 0.9474 & 0.9310 & 0.9454 \\
\hline $\mathrm{D}_{\mathrm{o}}$ & years & 150 & 150 & 150 & 150 \\
\hline $\mathrm{S}_{0}$ & $\mathrm{~g} \mathrm{C} \mathrm{m}^{-2}$ & 3702 & 3709 & 2514 & 3846 \\
\hline $\mathrm{R}_{\mathrm{s}}$ & ratio & 21.6 & 21.4 & 34.6 & 35.6 \\
\hline $\mathrm{M}_{\mathrm{r}}$ & $\mathrm{yr}^{-1}$ & 0.0249 & 0.0259 & 0.0711 & 0.0637 \\
\hline $\mathrm{L}_{\mathrm{n}}$ & $\mathrm{gN} \mathrm{g}^{-1}$ & 0.01 & 0.01 & 0.01 & 0.01 \\
\hline $\mathrm{W}_{\mathrm{n}}$ & $\mathrm{g} \mathrm{N} \mathrm{g}^{-1}$ & 0 & 0.001 & 0 & 0.001 \\
\hline $\mathrm{R}_{\mathrm{n}}$ & $\mathrm{g} \mathrm{N} \mathrm{g}^{-1}$ & 0.01 & 0.01 & 0.01 & 0.01 \\
\hline $\mathrm{T}_{\mathrm{f}}$ & fraction & 0.5 & 0.5 & 0.5 & 0.5 \\
\hline $\mathrm{N}_{\mathrm{d}}$ & $\mathrm{g} \mathrm{N} \mathrm{m}^{-2}$ & 0.7 & 0.7 & 0.7 & 0.7 \\
\hline $\mathrm{N}_{\mathrm{f}}$ & $\mathrm{g} \mathrm{N} \mathrm{m}^{-2}$ & 0.0 & 0.0 & 0.0 & 0.0 \\
\hline
\end{tabular}

\subsubsection{Root Turnover Times $\left(T_{b}\right)$}

Root turnover times for plant communities at Fort Benning were estimated on the basis of globally averaged root turnover rates in grasslands (50\% per year) and forests (10\% per year) (Gill and Jackson, 2000).

\subsubsection{Decomposition Rate of Fresh Litter Inputs $\left(D_{n}\right)$}

The mean residence time of soil $\mathrm{C}$ associated with above- and belowground litter inputs was derived by parameter fitting below an estimated upper limit. Based on regional estimates of 
forest litterfall (Sharpe et al., 1980) and a concentration of $0.5 \mathrm{~g} \mathrm{C} \mathrm{g}^{-1}$ litter, the estimated annual input of $\mathrm{C}$ to forest O-horizons at Fort Benning is $204 \mathrm{~g} \mathrm{C} \mathrm{m}^{-2}$. Measured mean $( \pm \mathrm{SE}) \mathrm{O}-$ horizon $\mathrm{C}$ stocks at 89 forest sites on Fort Benning were $423 \pm 19 \mathrm{~g} \mathrm{C} \mathrm{m}^{-2}$. Assuming the Ohorizon $\mathrm{C}$ stocks are at steady state, an upper limit to the mean residence time of fresh litter inputs at this site is $\approx 2$ years. The fitted mean residence times for fresh litter inputs to old field and forest soils (Table 5) were approximately half the estimated upper limit because the litter $\mathrm{C}$ inputs are underestimated by not considering belowground inputs from roots. The final fitted values for $\mathrm{D}_{\mathrm{n}}$ yielded steady state values for both potential excess $\mathrm{N}$ and soil $\mathrm{C}$ stocks in the model.

\subsubsection{Turnover Time of Mineral Soil Carbon $\left(D_{0}\right)$}

Soil $\mathrm{C}$ under transitional herbaceous vegetation and forests at Fort Benning includes $\approx 10 \%$ refractory $\mathrm{C}$ that is chemically similar to charcoal (Garten and Ashwood, 2004) and probably has a turnover time on the order of 1000 years. This refractory $\mathrm{C}$ originates from frequent use of controlled burning in land management. Most of the remaining $\mathrm{C}$ is found in mineral-associated soil organic matter (Garten and Ashwood, 2004) and is assumed to have a turnover time of 56 years based on data from multiple studies (Garten and Ashwood, 2002). The turnover time of mineral soil $\mathrm{C}$ under both forests and old fields was estimated as a weighted mean of the two pools (i.e., 150 years).

\subsubsection{Tissue Carbon and Nitrogen Concentrations}

It was assumed that biomass had a $\mathrm{C}$ concentration of $0.45 \mathrm{~g} \mathrm{C} \mathrm{g}^{-1}$ dry mass. Leaf $\mathrm{N}$ concentrations in the model were set at $1 \%$ based on data from multiple sources (Birk and Vitousek, 1986; Yin, 1993). Nitrogen concentrations in roots were assumed to equal those in foliage based on studies of loblolly pine on upper Coastal Plain sites (Birk and Vitousek, 1986). Concentrations of $\mathrm{N}$ in tree wood were set at $0.1 \%$ which approximates those measured in loblolly pine in the southeastern U.S. (Switzer et al., 1968; Birk and Vitousek, 1986).

\subsubsection{Translocation Factor $\left(\mathbf{T}_{\mathrm{f}}\right)$}

Seasonal translocation of $\mathrm{N}$ from foliar to woody tissues in trees (Luxmoore et al., 1981; Ostman and Weaver, 1982) and from aboveground tissues to roots in herbaceous plants (Li et al., 1992) is a well known process. The translocated $\mathrm{N}$ is available for production of new tissues at the beginning of the next growing season. In the model, the $\mathrm{N}$ requirements of photosynthetically active tissues were reduced each year based on the estimated $\mathrm{N}$ recycling within the plant. Studies of loblolly pine on sandy soils indicate that about $50 \%$ of the foliar N is translocated to wood prior to leaf senescence (Birk and Vitousek, 1986). Under conditions of low soil $\mathrm{N}$ availability, $\approx 50 \%$ of the $\mathrm{N}$ required for production of new biomass in herbaceous vegetation may be derived from internal translocation (e.g., Li et al., 1992). Therefore, in the absence of site-specific information, the translocation factor was set at $50 \%$ in both forests and old fields on Fort Benning. 


\subsubsection{Annual Nitrogen Deposition $\left(\mathbf{N}_{d}\right)$}

Based on data from the National Atmospheric Deposition Program, annual wet only $\mathrm{N}$ deposition in the Fort Benning area is $\approx 0.35 \mathrm{~g} \mathrm{~N} \mathrm{~m}^{-2}$. A scaling factor (2.0) to convert wet deposition to total $\mathrm{N}$ deposition (wet + dry) was derived from data previously collected at four sites in the southeastern U.S. (Lovett and Lindberg, 1993). Total annual N deposition in the model was set at $0.7 \mathrm{~g} \mathrm{~N} \mathrm{~m}^{-2}$.

\subsection{PREDICTED THRESHOLDS TO RECOVERY}

Table 5 presents a summary of the parameter values used to model thresholds to recovery for both old field and forest vegetation. Different parameter sets were used for old fields or forests depending on soil sand content. Many of the parameters (e.g., aboveground biomass targets, root:shoot ratio, and root turnover times) exhibited strong differences between the two ecosystems. However, some parameter values derived from field and laboratory studies (e.g., soil C: $\mathrm{N}$ ratios and annual potential rates of net soil $\mathrm{N}$ mineralization) were similar for different ecosystems within the same soil category.

Four factors were particularly important to development of a threshold event (i.e., a negative value for potential excess $\mathrm{N}$ ) during modeled ecosystem recovery : (1) initial amounts of aboveground biomass, (2) initial soil C stocks, (3) relative recovery rate of aboveground biomass, and (4) soil sand content. In this study, stocks of aboveground forest biomass were initialized by assuming $2 \%$ of the desired future condition (i.e., $360 \mathrm{~g} \mathrm{~m}^{-2}$ ) was present at the start of ecosystem recovery. Simulations of old fields were initialized by assuming aboveground biomass was $25 \%$ of the desired future condition (i.e., $90 \mathrm{~g} \mathrm{~m}^{-2}$ ) at the start of ecosystem recovery.

Initial soil C stocks in the model determined predicted patterns of recovery by both old field and forest ecosystems. Figure 2 illustrates the predicted recovery of (a) aboveground biomass, (b) potential excess $\mathrm{N}$, and (c) soil C stocks for two different soils (1000 and $2000 \mathrm{~g}$ soil $\mathrm{C} \mathrm{m}^{-2}$ ) in old field ecosystems on "more sandy" soils. Starting from an initial stock of $1000 \mathrm{~g}$ soil $\mathrm{C} \mathrm{m}^{-2}$, a nutrient threshold to recovery was crossed in the fourth year. Predicted potential excess $\mathrm{N}$ remained negative for the duration of the simulation indicating that the desired future condition ( $360 \mathrm{~g} \mathrm{~m}^{-2}$ aboveground biomass) could not be achieved. Starting from an initial stock of $2000 \mathrm{~g}$ soil $\mathrm{C} \mathrm{m}^{-2}$, predicted potential excess $\mathrm{N}$ was positive $\left(1 \mathrm{~g} \mathrm{~N} \mathrm{~m}^{-2}\right)$ indicating the desired future condition was achievable and sustainable for old fields on "more sandy" soils. In the latter case, predicted soil C stocks increased by about $12 \%$ over 50 years.

In the model, a slower recovery rate $\left(\mathrm{B}_{\mathrm{r}}\right)$ could prevent forests from crossing a nutrient threshold during ecosystem recovery. Figure 3 illustrates the change in (a) aboveground biomass, (b) potential excess $\mathrm{N}$, and (c) soil $\mathrm{C}$ stocks over 120 years at two different rates of forest growth. Starting from an initial condition of $1700 \mathrm{~g}^{\text {soil } \mathrm{C} \mathrm{m}^{-2}}(90 \%$ of the barren sites examined at Fort Benning had soil $\mathrm{C}$ stocks less than this value), and at a default recovery rate of $0.15 \mathrm{yr}^{-1}$, 


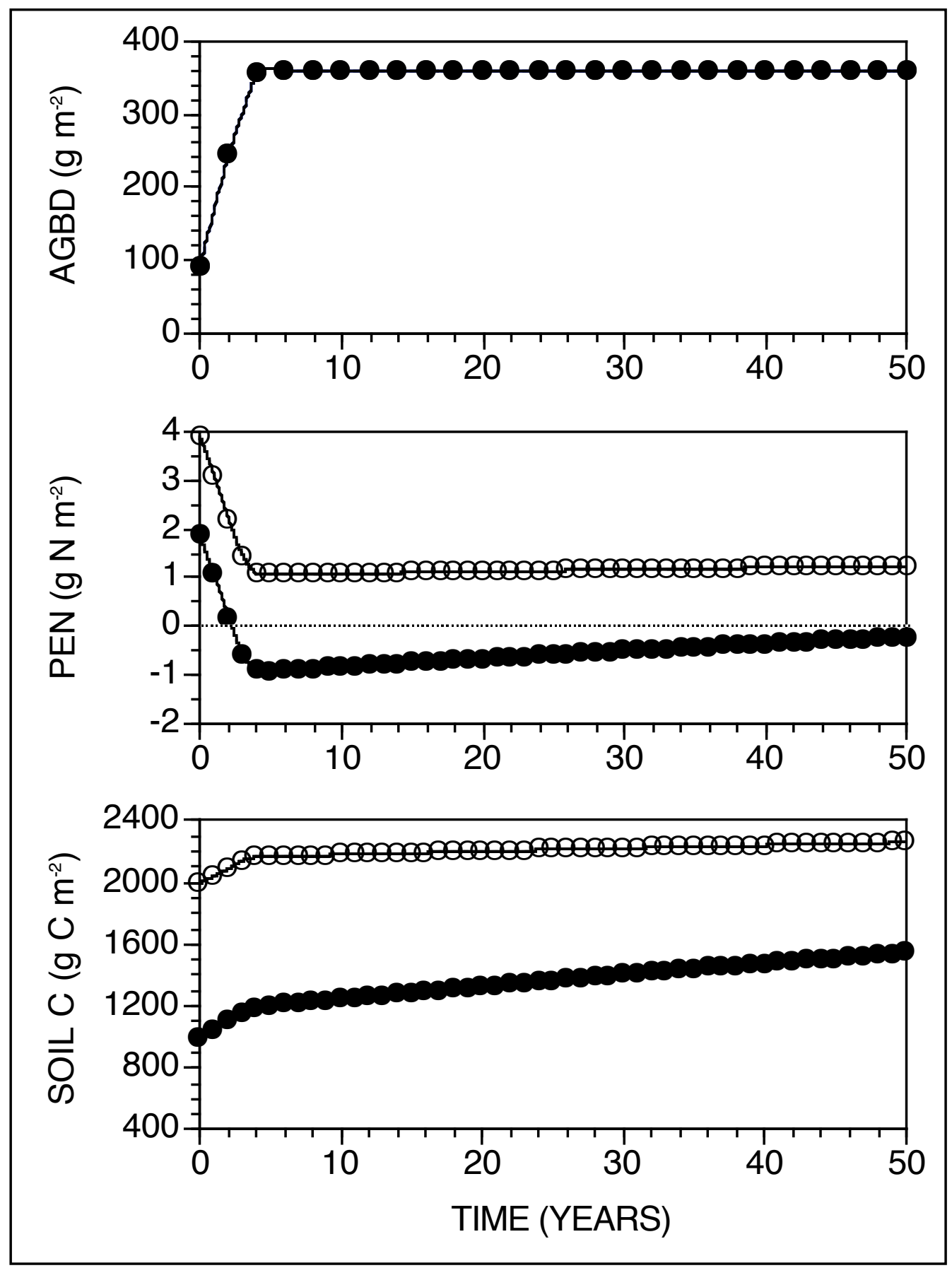

Fig. 2. Predicted recovery of aboveground biomass density (AGBD) (upper panel), potential excess N (PEN) (middle panel), and soil C stocks (lower panel) for old field development on soils with two different levels of initial soil $\mathrm{C}$ stocks at Fort Benning,

GA. Starting from $1000 \mathrm{~g} \mathrm{C} \mathrm{m}^{-2}$ soil (closed circles), predicted PEN values quickly become negative (middle panel) indicating that a nutrient threshold precludes ecosystem recovery at the specified recovery rate (see text). Calculations with the model indicate that old field recovery, as illustrated in the upper and bottom panels, is possible starting from $2000 \mathrm{~g} \mathrm{C} \mathrm{m}^{-2}$ soil (open circles). 


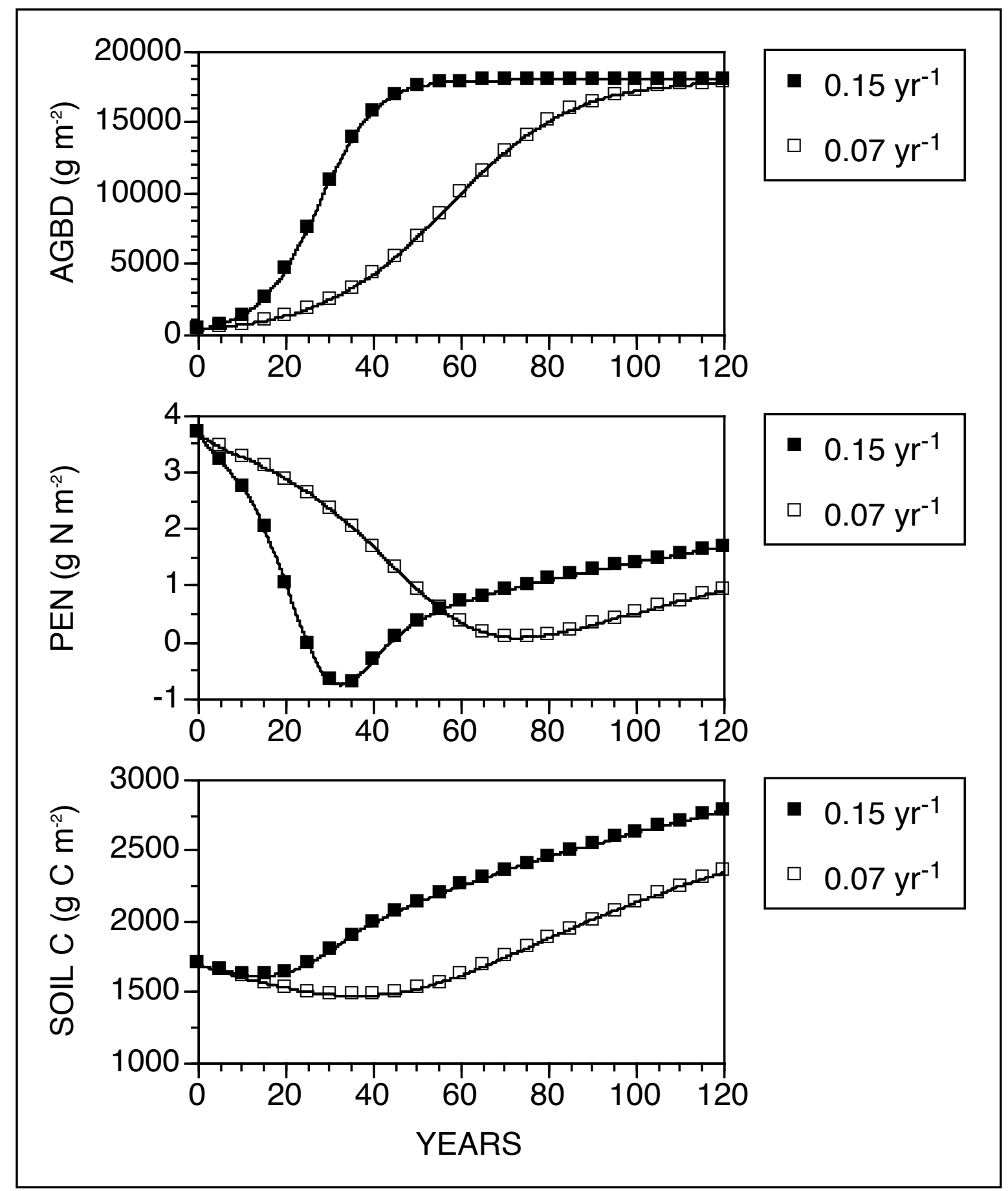

Fig. 3. Predicted recovery of aboveground biomass density (AGBD) (upper panel), potential excess $\mathbf{N}$ (PEN) (middle panel), and soil C stocks (lower panel) for forest ecosystems with different recovery rates at Fort Benning, GA. When the recovery rate is $0.15 \mathrm{yr}^{-1}$, then predicted PEN values are negative indicating that a nutrient threshold precludes ecosystem recovery (see text). Calculations with the model indicate that forest recovery, as shown in the upper and bottom panels, is possible when the recovery rate is reduced to $0.07 \mathrm{yr}^{-1}$. 
the desired future condition for aboveground forest biomass was theoretically attained in $\approx 50$ years. However, at the default recovery rate, potential excess $\mathrm{N}$ becomes negative from 25 to 45 years into the simulation indicating $\mathrm{N}$ deficiency could prevent recovery to the desired future condition with the specified parameter set. Even though the accumulation of soil organic matter was slower when the growth rate was lowered to $0.07 \mathrm{yr}^{-1}$, a nutrient threshold to forest recovery was not crossed and the desired future condition for forest biomass was achieved following 110 years of forest growth.

Predicted thresholds to recovery for forests and old fields at Fort Benning are illustrated in Figure 4. The various lines in the graph define initial soil C stocks that allow recovery to a desired future condition with the model (using the parameter sets presented in Table 5). Above

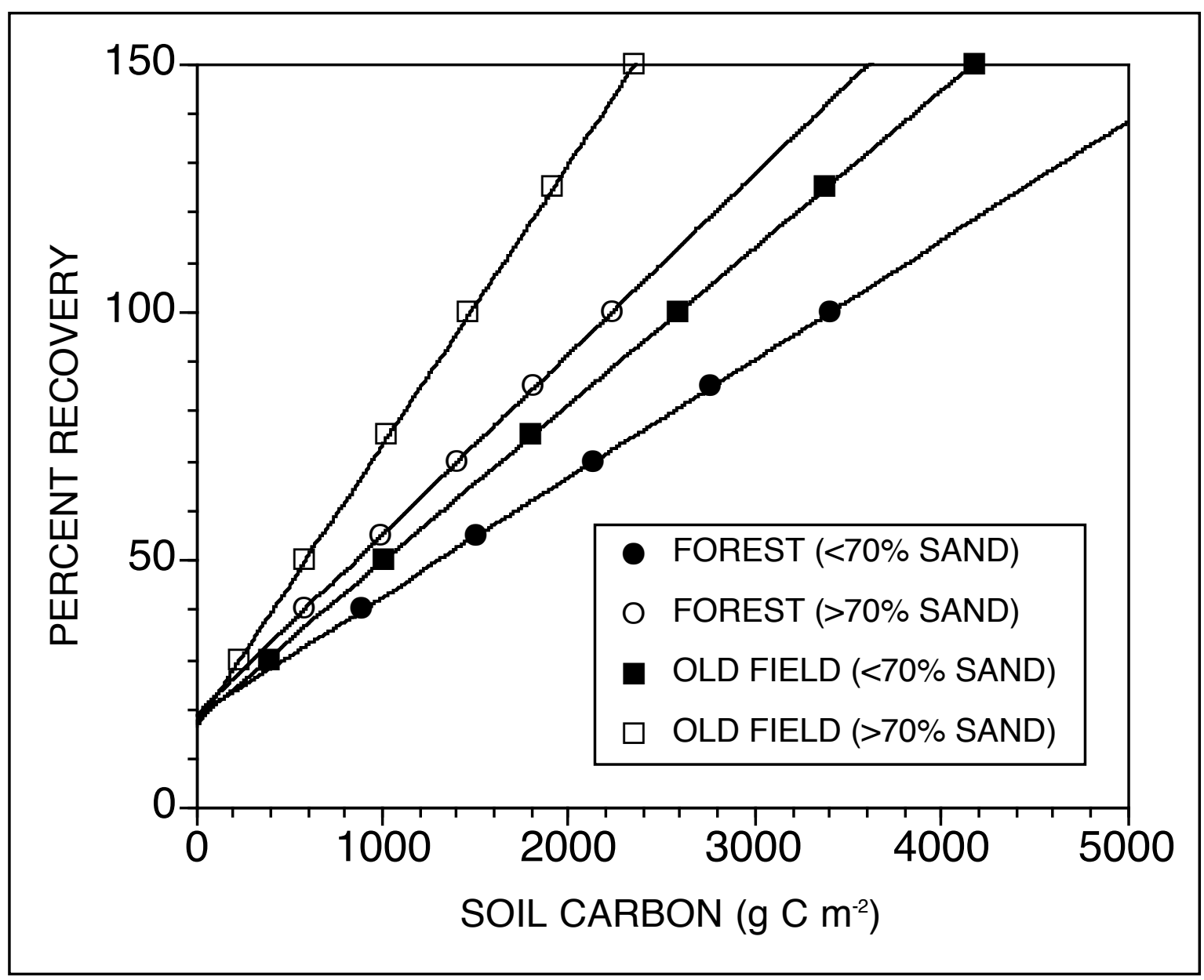

Fig. 4. Predicted thresholds to recovery for old field and forest ecosystems on more sandy ( $>70 \%$ sand content) and less sandy ( $<70 \%$ sand content) soils at Fort Benning, GA. Nutrient thresholds to recovery exist in the region above each line. In the region below each line, ecosystem recovery proceeds to a desired future condition without crossing a threshold (i.e., negative potential excess $\mathrm{N}$ ). The predicted thresholds depend on the specified recovery rate (see text). 
each line, the predicted potential excess $\mathrm{N}$ becomes negative at some time during the simulation of ecosystem recovery while below each line ecosystem recovery proceeds to the desired future condition with continuously positive potential excess N. For example, starting from an initial condition of $2000 \mathrm{~g}$ soil $\mathrm{C} \mathrm{m}^{-2}$ on soils with less than $70 \%$ sand content, the model predicts recovery to $80 \%$ of the desired future condition in old fields without crossing a threshold to recovery (i.e., a negative potential excess $\mathrm{N}$ ). Higher percent recoveries cannot be achieved because the nutrient threshold is crossed. Stated in another way, the model predicts recovery to $80 \%$ of the desired future condition for old fields on "less sandy" soils at Fort Benning can be achieved from an initial starting soil quality of $2000 \mathrm{~g} \mathrm{C} \mathrm{m}^{-2}$ or greater.

Forests and old fields on soils with differing sand content had different predicted thresholds to recovery (Figure 4). Within each ecosystem type, predicted soil N stocks were greater on less sandy soils due to their lower soil $\mathrm{C}: \mathrm{N}$ ratios. However, rates of annual potential net soil $\mathrm{N}$ mineralization, derived from laboratory incubations, were higher on more sandy soils than less sandy soils. Consequently, predicted thresholds to recovery of old fields and forests were lower on soils with more than $70 \%$ sand content. For example, the model predicted $100 \%$ forest recovery at $\approx 2200 \mathrm{~g} \mathrm{C} \mathrm{m}^{-2}$ on more sandy soils but only $70 \%$ recovery on less sandy soils with the same soil $\mathrm{C}$ stock (Fig. 4). More sandy soils under perennial vegetation had a significantly $\left(\mathrm{F}_{1,107}=17.5 ; P<0.001\right)$ greater fraction of soil $\mathrm{C}$ in POM and significantly $\left(\mathrm{F}_{1,107}=\right.$ 4.2, $P<0.05$ ) greater stocks of surface mineral soil POM carbon than less sandy soils (Fig. 5). Particulate organic matter is a highly labile $\mathrm{C}$ pool that may be important to $\mathrm{N}$ retention and availability in some soils (e.g., Hook and Burke, 2000; Willson et al., 2001). Greater amounts of labile soil organic matter may be one factor contributing to higher potential net soil $\mathrm{N}$ mineralization rates in more sandy soils at Fort Benning.

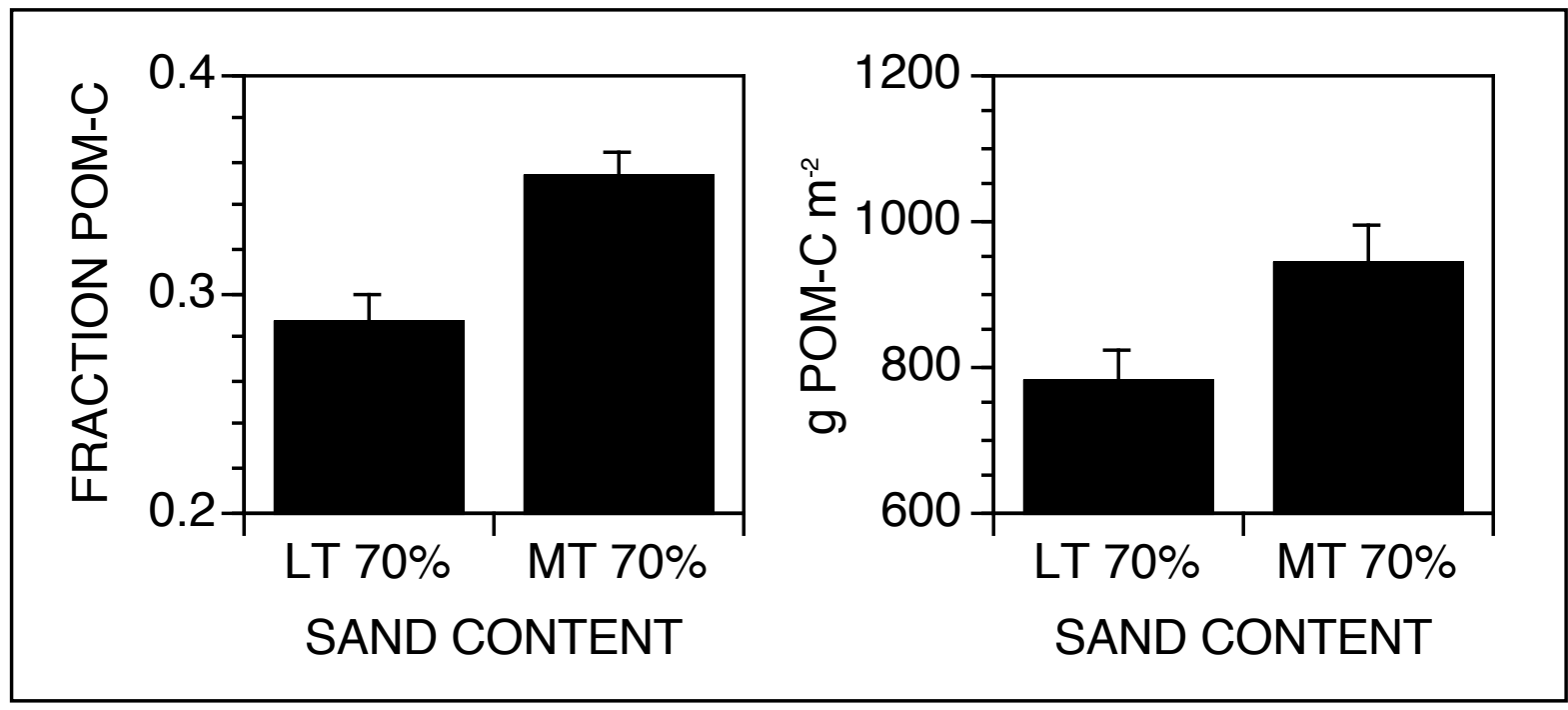

Fig. 5. Fraction of surface $(0-20 \mathrm{~cm})$ soil $\mathrm{C}$ associated with particulate organic matter (left panel) and stocks of POM carbon (right panel) in soils with less than (LT) or more than (MT) 70\% sand content under perennial vegetation at Fort Benning, GA. 
Using the parameter sets presented in Table 5, barren sites at Fort Benning generally lie below predicted thresholds to $100 \%$ recovery of desired future conditions. The $95 \%$ confidence interval about mean soil $\mathrm{C}$ stocks on barren land at Fort Benning was 313 to $944 \mathrm{~g} \mathrm{C} \mathrm{m}^{-2}$. On more sandy soils (typical of barren sites), predicted forest recoveries exceeding $55 \%$ of the desired future condition cross the nutrient threshold to recovery at $\approx 950 \mathrm{~g} \mathrm{C} \mathrm{m}^{-2}$. However, at the default recovery rates (Table 5), the model predicts up to $70 \%$ recovery of old field biomass can be achieved from an initial soil $\mathrm{C}$ stock of $950 \mathrm{~g} \mathrm{C} \mathrm{m}^{-2}$ and up to $50 \%$ recovery can be achieved from an initial soil $\mathrm{C}$ stock of $600 \mathrm{~g} \mathrm{C} \mathrm{m}^{-2}$. Figure 6 further illustrates the effect of varying recovery rate and percent recovery on calculated thresholds to forest recovery on less sandy and more sandy soils at Fort Benning. Predicted recovery to $100 \%$ of the desired future condition, without crossing a threshold in $\mathrm{N}$ availability, is indicated even at relatively low initial soil $\mathrm{C}$ stocks on more sandy soils, but only at low recovery rates.

\section{DISCUSSION}

The concept of thresholds has not been widely applied in ecosystem management (Brown et al., 1999). Ecologists have been successful in identifying factors associated with

thresholds (e.g., nutrient loading leading to eutrophication, overgrazing leading to the loss of range land, habitat fragmentation leading to loss of biodiversity), but threshold quantification has been more problematic. In some cases, a single well-defined threshold may not exist or the threshold may depend on site-specific factors that make predictions beyond the local conditions difficult or impossible. In other cases, thresholds may be influenced by one or more factors that are indirectly related to the stimulus or stress that causes a response. Given the large likelihood that no two ecosystems are totally identical in time or in space, we can expect natural variation in thresholds from one time to another and from one location to another.

Relatively intensive monitoring of ecosystem structure and function may be required for empirical detection and quantification of ecological thresholds (Muradian, 2001).

Reestablishment of vegetation and recovery of soil quality on degraded soils can be a long-term process requiring decades to centuries, thus (with the possible exception of chronosequence studies) empirical investigations directed at discerning nutrient thresholds to ecosystem recovery are impractical. Periodic measurements of indicators of ecosystem "health" may be sufficient to ascertain general trends, but considering the extent of spatial and temporal variation in natural systems, the level of monitoring required to detect thresholds through field studies is, practically speaking, prohibitively expensive. Furthermore, some thresholds may only be recognized "after the fact" from analysis of long-term monitoring data (in which case it may be too late for land managers to initiate corrective actions). There is a much higher probability of detecting an ecological threshold when a system "jumps" to an entirely new state or undergoes total collapse as a result of a recognizable disturbance (e.g., hurricane, disease, crown fire, or overgrazing), particularly when such a change is manifested as a sudden and dramatic difference in vegetation structure (like the creation of barren land through soil disturbance). 


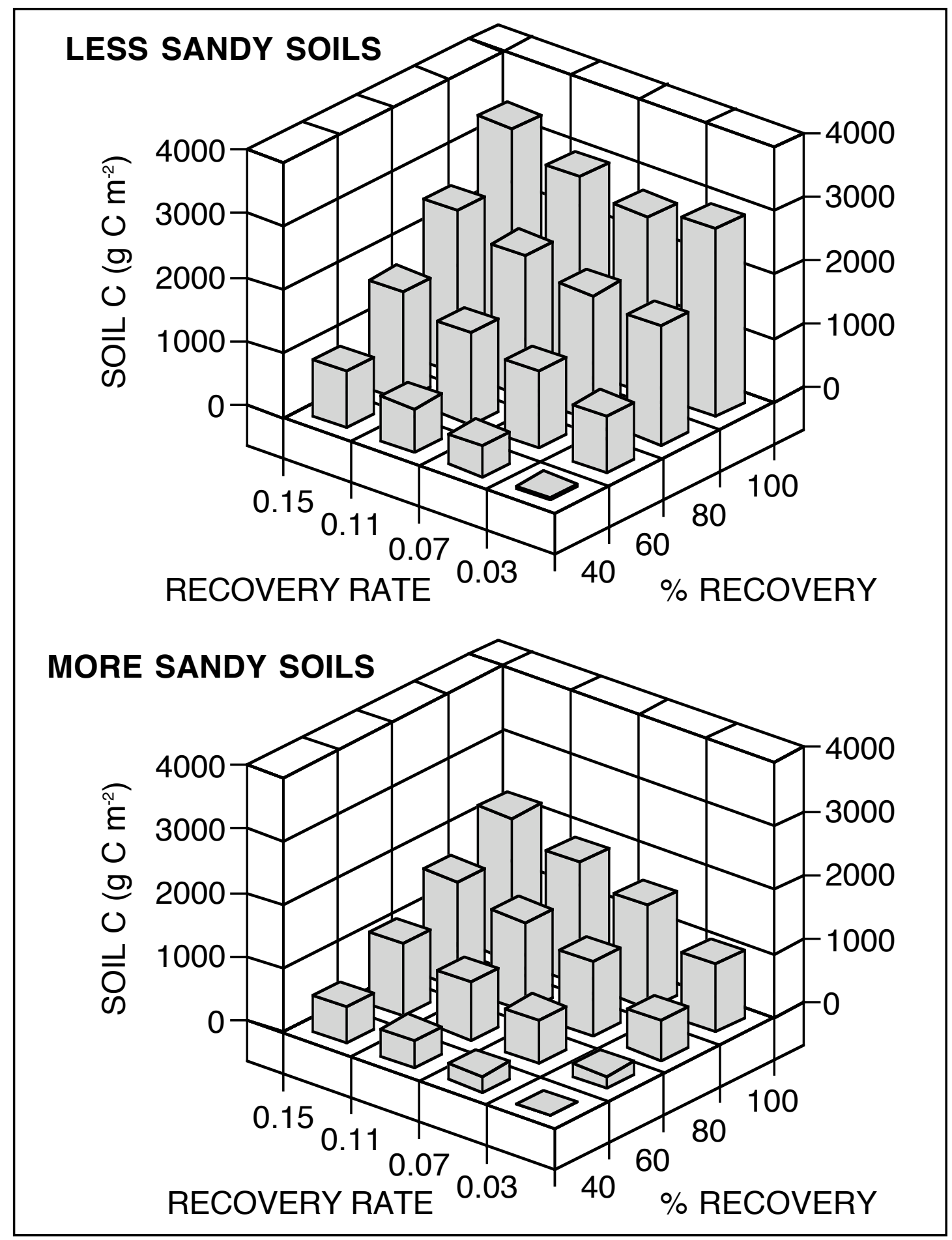

Fig. 6. Predicted thresholds to forest recovery (expressed as initial soil $\mathbf{C}$ stocks) on more sandy ( $>70 \%$ sand content) and less sandy $(<70 \%$ sand content) soils as a function of recovery rate $\left(\mathrm{yr}^{-1}\right)$ and percent recovery to a desired future condition $(18000 \mathrm{~g}$ aboveground biomass $\mathbf{m}^{-2}$ ). When soil $\mathrm{C}$ stocks are less than those shown, recovery to the desired future condition at the indicated recovery rate is theoretically precluded by a deficiency in soil $\mathrm{N}$ availability at time point during forest development. 
In this research, simple mathematical models of $\mathrm{C}$ and $\mathrm{N}$ (as indices of soil quality) are used to predict a nutrient resource threshold to ecosystem recovery. Biomass production in the southeastern U.S. is often limited by available soil N (Fisher and Garbett, 1980; Birk and Vitousek, 1986; Vose and Allen, 1991), thus the current model is developed around N limitation to the achievement of a desired future condition, measured in terms of aboveground standing crop biomass and a specified recovery rate. Modeling is usually an oversimplification, and it is certainly no less so in the present study, but the use of models for estimation of thresholds to ecosystem recovery can meet two important needs: (1) the use of site-specific information for critical parameter values, and (2) the removal of constraints associated with evaluating thresholds from a limited set of apriori conditions (as is frequently the case in empirical studies). Furthermore, in mathematical models, thresholds can be posed as simple "true or false" questions; or framed such that a threshold test indicates if a situation will or will not occur.

Mathematical models have their own unique set of problems when applied to the estimation of ecological thresholds (Moir and Mowrer, 1995; Hansen and Jones, 1996). Errors in model structure and parameterization can lead to erroneous predictions of thresholds or, at least, contribute to large, unknown uncertainties in the accuracy of estimated thresholds. In addition, there is a pervasive skepticism about the usefulness of models (e.g., Passioura, 1996), whether they be simple or complex. Complex models may give greater representation to system properties and processes, but they are more difficult to understand, parameterize, and verify (Schoenholtz et al., 2000). Simple models are easier to use and understand but may neglect important system properties or processes.

Calculations with the model indicate that thresholds to ecosystem recovery from degraded land, expressed as initial soil C stocks, are lower on more sandy soils than on less sandy soils at Fort Benning. The lower thresholds for old field and forest recovery on more sandy soils are largely due to higher estimated relative rates of net soil $\mathrm{N}$ mineralization in more sandy soils. Correct parameterization of net soil $\mathrm{N}$ mineralization is particularly important to the accurate estimation of thresholds to ecosystem recovery. If rates of potential net soil $\mathrm{N}$ mineralization are overestimated in the model, then predicted thresholds to recovery (expressed as initial soil $\mathrm{C}$ stocks) are underestimated. At near steady-state soil $\mathrm{C}$ and $\mathrm{N}$ stocks, the calculated soil $\mathrm{N}$ mineralization flux in the model ranged from about 4 to $6 \mathrm{~g} \mathrm{~N} \mathrm{~m}^{-2} \mathrm{yr}^{-1}$ and approximated the annual in situ mineralization flux (about $5 \mathrm{~g} \mathrm{~N} \mathrm{~m}^{-2}$ ) measured in uncut loblolly pine plantations growing on the North Carolina Piedmont (Vitousek and Matson, 1985). The calculated rates from Fort Benning are, however, substantially greater than previously measured in situ net soil $\mathrm{N}$ mineralization rates $\left(0.5\right.$ to $\left.1.2 \mathrm{~g} \mathrm{~N} \mathrm{~m}^{-2}\right)$ in longleaf pine ecosystems on the coastal plain in southwest Georgia, which the investigators (Wilson et al., 1999) acknowledge as "among the lowest rates recorded for North American forests". Such differences between studies in soil $\mathrm{N}$ availability reinforce the need for site-specific information when models are used to estimate nutrient thresholds to ecosystem recovery.

Much is already known about the development of old fields and their importance in 
secondary ecological succession, $\mathrm{N}$ accrual, and ecosystem recovery on degraded or abandoned agricultural land (Keever,1950; Odum, 1960; Wiegert and Evans, 1964; Robles and Burke, 1997; Knops and Tilman, 2000), but more site specific information is needed before $\mathrm{N}$ fixation at Fort Benning can be accurately represented in the current model. Frequent controlled burning may promote the establishment and persistence of legumes in southern pine ecosystems, but the annual contribution of these legume populations to overall ecosystem $\mathrm{N}$ balance is relatively small $\left(<1 \mathrm{~g} \mathrm{~N} \mathrm{~m}^{-2}\right)$ and may merely balance $\mathrm{N}$ losses incurred through prescribed burning (Hendricks and Boring, 1999). Nitrogen fixation on the order of $2 \mathrm{~g} \mathrm{~N} \mathrm{~m}^{-2} \mathrm{yr}^{-1}$ was reported by Jorgensen and Wells (1971) in annually burned loblolly pine stands on the lower coastal plain of South Carolina, but the process exhibited a high degree of spatial variability. Other studies indicate a decline in biological $\mathrm{N}$ fixation well before a decline in $\mathrm{N}$ accrual during ecological succession (Rastetter et al., 2001) and that atmospheric deposition may contribute more to $\mathrm{N}$ accrual during forest regrowth on abandoned agricultural land in the southeastern U.S. than $\mathrm{N}$ fixation (Richter et al., 2000) . Thus, the omission of $\mathrm{N}$ fixation in the current model may not seriously bias calculated thresholds to ecosystem recovery.

Finally, calculations with the model indicate that a combination of desired future conditions, initial levels of soil quality (defined by soil C stocks), and the rate of biomass accumulation determines the predicted success of ecosystem recovery on disturbed soils. Thresholds to ecosystem recovery predicted by the model should not be interpreted independent of the specified recovery rate to a desired future condition. This is best illustrated by graphing thresholds to forest recovery (expressed as initial soil C stocks) as a function of percent recovery to a desired future condition and recovery rate on less sandy and more sandy soils at Fort Benning (Fig. 6). Thresholds of soil C stocks do not indicate that ecosystem recovery is strictly precluded, only that it is precluded at a specified rate of aboveground biomass accumulation. A lack of feedback between soil $\mathrm{N}$ availability and the rate of biomass accumulation in the model causes the ecosystem to grow into a state of $\mathrm{N}$ deficiency (i.e., negative potential excess $\mathrm{N}$ ). In a similar fashion, forests developing on nutrient poor soils in the southeastern U.S. tend to grow into a state of acute $\mathrm{N}$ deficiency that eventually limits biomass production (Richter et al., 2000; Gholz et al., 1985). Within the constraints imposed by soil organic matter, ecosystem recovery is also related to the frequency of disturbance and land management actions (e.g., fertilization) that affect soil quality and productivity of vegetation. In this respect, the threshold model can be used to predict how much and how long $\mathrm{N}$ fertilizer would need to be applied to enable ecosystem recovery from a specified initial level of soil organic matter at Fort Benning, Georgia. 


\section{REFERENCES}

Alakukku, L., and Elonen, P. 1995. Long-term effects of a single compaction by heavy field traffic on yield and nitrogen uptake of annual crops. Soil and Tillage Research 36: 141-152.

Arshad, M.A., and Martin, S. 2002. Identifying critical limits for soil quality indicators in agroecosystems. Agriculture Ecosystems and Environment 88: 153-160.

Birk, E.M., and Vitousek, P.M. 1986. Nitrogen availability and nitrogen use efficiency in loblolly pine stands. Ecology 67: 69-79.

Braunack, M.V. 1986. The residual effects of tracked vehicles on soil surface properties. Journal of Terramechanics 23: 37-50.

Bray, J.R., and Gorham, E. 1964. Litter production in forests of the world. Advances in Ecological Research 2: 101-157.

Brown, J.R., Herrick, J., and Price, D. 1999. Managing low-output agroecosystems sustainability: the importance of ecological thresholds. Canadian Journal of Forest Research 29: 1112-1119.

Brown, S., Schroeder, P., and Birdsey, R. 1997. Aboveground biomass distribution of US eastern hardwood forests and the use of large trees as an indicator of forest development. Forest Ecology and Management 96: 37-47.

Cairns, M.A., Brown, S., Helmer, E.H., and Baumgardner, G.A. 1997. Root biomass allocation in the world's upland forests. Oecologia 111: 1-11.

Davenport, D.W., Breshears, D.D., Wilcox, B.P., and Allen, C.D. 1998. Viewpoint: sustainability of pinon-juniper ecosystems -- a unifying perspective of soil erosion thresholds. Journal of Range Management 51: 231-240.

Fisher, R.F., and Garbett,W.S. 1980. Response of semi-mature slash and loblolly pine plantations to fertilization with nitrogen and phosphorus. Soil Science Society America Journal 44: 850-854.

Garten, C.T., Jr., and Ashwood, T.L. 2002. Landscape level differences in soil carbon and nitrogen: implications for soil carbon sequestration. Global Biogeochemical Cycles 16: article no. 1114.

Garten, C.T., Jr., and Ashwood, T.L. 2004. Land cover differences in soil carbon and nitrogen at Fort Benning, Georgia. ORNL/TM-2004/14. Oak Ridge National Laboratory, Oak Ridge, TN 37830 
Garten, C.T., Jr., Ashwood, T.L., and Dale, V.H. 2003. Effect of military training on indicators of soil quality at Fort Benning, Georgia. Ecological Indicators 3: 171-179.

Gholz, H.L., Fisher, R.F., and Pritchett, W.L. 1985. Nutrient dynamics in slash pine plantation ecosystems. Ecology 66: 647-659.

Gill, R.A., and Jackson, R.B. 2000. Global patterns of root turnover for terrestrial ecosystems. The New Phytologist 147: 13-31.

Hansen, J.W., and Jones, J.W. 1996. A systems framework for characterizing farm sustainability. Agricultural Systems 51: 185-201.

Hart, S.C., Stark, J.M., Davidson, E.A., and Firestone, M.K. 1994. Nitrogen mineralization, immobilization, and nitrification. Methods of Soil Analysis, Part 2. Microbiological and Biochemical Processes (eds. R.W. Weaver, S. Angle, P. Bottomley, D. Bezdiecek, S. Smith, A. Tabatabai, and A. Wollum), pp. 985-1018. Soil Science Society of America, Madison, WI.

Hatchell, G.E., Ralston, C.W., and Foil, R.R. 1970. Soil disturbances in logging. Journal of Forestry 68: 772-775.

Hendricks, J.J., and Boring, L.R. 1999. $\mathrm{N}_{2}$-fixation by native herbaceous legumes in burned pine ecosystems of the southeastern United States. Forest Ecology and Management 113: 167-177.

Hook, P.B., and Burke, I.C. 2000. Biogeochemistry in a shortgrass landscape: control by topography, soil texture, and microclimate. Ecology 81: 2686-2703.

Hunter, M.L., and White, A.S. 1997. Ecological thresholds and the definition of old-growth forest stands. Natural Areas Journal 17: 292-296.

Hussain, I., Olson, K.R., Wander, M.M., and Karlen, D.L. 1999. Adaptation of soil quality indices and application to three tillage systems in southern Illinois. Soil and Tillage Research 50: 237-249.

Iverson, R.M., Hinckley, B.S., Webb, R.M., and Hallet, B. 1981. Physical effects of vehicular disturbance on arid landscapes. Science 212: 915-917.

Jackson, R.B., Canadell, J., Ehleringer, J.R., Mooney, H.A., Sala, O.E., and Schulze, E.D. 1996. A global analysis of root distributions for terrestrial biomes. Oecologia 108: 389-411.

Johnson, D.W., and Van Hook, R.I. (eds.) 1989. Analysis of Biogeochemical Cycling Processes in Walker Branch Watershed. Springer-Verlag, New York. 
Johnson, D.W., and Lindberg, S.E. (eds.) 1992. Atmospheric Deposition and Forest Nutrient Cycling: A Synthesis of the Integrated Forest Study. Springer-Verlag, New York.

Jones, D.S., and Davo, T. 1997. Land Condition-Trend Analysis Program Summary, Fort Benning, Georgia: 1991-1995. Center for Ecological Management of Military Lands, Colorado State University, Fort Collins, CO.

Jorgensen, J.R., and Wells, C.G. 1971. Apparent nitrogen fixation in soil influenced by prescribed burning. Soil Science Society America Journal 35: 806-810.

Keever, C. 1950. Causes of succession on old fields of the Piedmont, North Carolina. Ecological Monographs 20: 229-250.

Kelly, J.M. 1975. Dynamics of root biomass in two eastern Tennessee old field communities. American Midland Naturalist 94: 54-61.

Knops, J.M.H., and Tilman, D. 2000. Dynamics of soil nitrogen and carbon accumulation for 61 years after agricultural abandonment. Ecology 81: 88-98.

Lande, R., B.E. Saether, and Engen, S. 1997. Threshold harvesting for sustainability of fluctuating resources. Ecology 78: 1341-1350.

Lewandowski, I., Hardtlein, M., and Kaltschmitt, M. 1999. Sustainable crop production: definition and methodological approach for assessing and implementing sustainability. Crop Science 39: 184-193.

Li, Y.S., Redmann, R.E., and Kessel, C.V. 1992. Nitrogen budget and ${ }^{15} \mathrm{~N}$ translocation in perennial wheatgrass. Functional Ecology 6: 221-225.

Lovett, G.M., and Lindberg, S.E. 1993. Atmospheric deposition and canopy interactions of nitrogen in forests. Canadian Journal of Forest Research 23: 1603-1616.

Luxmoore, R.J., Grizzard, T., and Strand, R.H. 1981. Nutrient translocation in the outer canopy and understory of an eastern deciduous forest. Forest Science 27: 505-518.

Milchunas, D.G., Schulz, K.A., and Shaw, R.B. 1999. Plant community responses to disturbance by mechanized military maneuvers. Journal of Environmental Quality 28: 15331547.

Mitchell, R.J., Kirkman, L.K., Pecot, S.D., Wilson, C.A., Palik, B.J., and Boring, L.R. 1999. Patterns and controls of ecosystem function in longleaf pine - wiregrass savannas. I. Aboveground net primary productivity. Canadian Journal of Forest Research 29: 743-751. 
Moir, W.H., and Mowrer, H.T. 1995. Unsustainability. Forest Ecology and Management 73: 239-248.

Muradian, R. 2001. Ecological thresholds: a survey. Ecological Economics 38: 7-24.

Odum, E.P. 1960. Organic production and turnover in old field succession. Ecology 41: 34-49.

Ostman, N.L., and Weaver, G.T. 1982. Autumnal nutrient transfers by retranslocation, leaching, and litter fall in a chestnut oak forest in southern Illinois. Canadian Journal of Forest Research 12: 41-51.

Page-Dumroese, D., Jurgensen, M., Elliot, W., Rice, T., Nesser, J., Collins, T., and Meurisse, R. 2000. Soil quality standards and guidelines for forest sustainability in northwestern North America. Forest Ecology and Management 138: 445-462.

Passioura, J.B. 1996. Simulation models: science, snake oil, education, or engineering? Agronomy Journal 88: 690-694.

Prose, D.V. 1985. Persisting effects of armored military maneuvers on some soils of the Mojave Desert. Environmental Geology and Water Sciences 7: 163-170.

Rastetter, E.B., Vitousek, P.M., Field, C., Shaver, G.R., Herbert, D., and Agren, G.I. 2001. Resource optimization and symbiotic nitrogen fixation. Ecosystems 4: 369-388.

Richter, D.D., Markewitz, D., Heine, P.R., Jin, V., Raikes, J., Tian, K., and Wells, C.G. 2000. Legacies of agriculture and forest regrowth in the nitrogen of old-field soils. Forest Ecology and Management 138: 233-248.

Robles, M.D., and Burke, I.C. 1997. Legume, grass, and conservation reserve program effects on soil organic matter recovery. Ecological Applications 7: 345-357.

Romme, W.H., Everham, E.H., Frelich, L.E., Moritz, M.A., and Sparks, R.E. 1998. Are large, infrequent disturbances qualitatively different from small, frequent disturbances? Ecosystems 1: 524-534.

Schoenholtz, S.H., Van Miegroet, H., and Burger, J.A. 2000. A review of chemical and physical properties as indicators of forest soil quality: challenges and opportunities. Forest Ecology and Management 138: 335-356.

Seybold, C.A., Mausbach, M.J., Karlen, D.L., and Rogers, H.H. 1997. Quantification of soil quality. Soil Processes and the Carbon Cycle (eds. R. Lal, J.M. Kimble, R.F. Follett, and B.A. Stewart), pp. 387-404. CRC Press, Boca Raton, FL 
Sharpe, D.M., Cromack, Jr., K., Johnson, W.C., and Ausmus, B.S. 1980. A regional approach to litter dynamics in southern Appalachian forests. Canadian Journal of Forest Research 10: 395-404.

Sikora, L.J., Yakovchenko, Y., Cambardella, C.A., and Doran, J.W. 1996. Assessing soil quality by testing organic matter. Soil Organic Matter: Analysis and Interpretation (eds. F.R. Magdoff, M.A. Tabatabai, and E.A. Hanlon, Jr.), pp. 41-50. Soil Science Society of America, Madison, WI.

Slob, W. 1999. Thresholds in toxicology and risk assessment. International Journal of Toxicology 18: 259-268.

Switzer, G.L., Nelson, L.E., and Smith, W.H. 1968. The mineral cycle in forest stands. Forest Fertilization: Theory and Practice, pp. 1-9. Tennessee Valley Authority, National Fertilizer Development Center, Muscle Shoals, AL

Thurow, T.L., Warren, S.D., and Carlson, D.H. 1993. Tracked vehicle traffic effects on the hydrologic characteristics of central Texas rangeland. Transactions of the American Society of Agricultural Engineers 36: 1645-1650.

Van Straalen, N.M. 1997. How to measure no effect. 2. Threshold effects in ecotoxicology. Environmetrics 8: 249-253.

Verburg, P.S.J., and Johnson, D.W. 2001. A spreadsheet-based biogeochemical model to simulate nutrient cycling processes in forest ecosystems. Ecological Modelling 141: 185-200.

Vitousek, P.M., and Matson, P.A. 1985. Disturbance, nitrogen availability, and nitrogen losses in an intensively managed loblolly pine plantation. Ecology 66: 1360-1376.

Voorhees, W.B., Nelson, W.W., and Randall, G.W. 1986. Extent and persistence of subsoil compaction caused by heavy axle loads. Soil Science Society America Journal 50: 428-433.

Vose, J.M., and Allen, H.L. 1991. Quantity and timing of needlefall in N and P fertilized loblolly-pine stands. Forest Ecology and Management 41: 205-219.

Wail, M.K., Evrendilek, F., West, T.O., Watts, S.E., Pant, D., Gibbs, H.K., and McClead, B.E. 1999. Assessing terrestrial ecosystem sustainability: usefulness of regional carbon and nitrogen models. Nature and Resources 35: 21-33.

Whalen, J.K., Bottomley, P.J., and Myrold, D.D. 2000. Carbon and nitrogen mineralization from light- and heavy-fraction additions to soil. Soil Biology and Biochemistry 32: 1345-1352.

Wiegert, R.G., and Evans, F.C. 1964. Primary production and the disappearance of dead 
vegetation on an old field in southeastern Michigan. Ecology 45: 49-63.

Willson, T.C., Paul, E.A., and Harwood, R.R. 2001. Biologically active soil organic matter fractions in sustainable cropping systems. Applied Soil Ecology 16: 63-76.

Wilson, C.A., Mitchell, R.J., Hendricks, J.J., and Boring, L.R. 1999. Patterns and controls of ecosystem function in longleaf pine - wiregrass savannas. II. Nitrogen dynamics. Canadian Journal of Forest Research 29: 752-760.

Woolf, H.B., ed. 1975. Webster's New Collegiate Dictionary. G. \& C. Merriam, Springfield, MA

Yin, X. 1993. Variation in foliar nitrogen concentration by forest type and climatic gradients in North America. Canadian Journal of Forest Research 23: 1587-1602.

Zinck, J.A., and Farshad, A. 1995. Issues of sustainability and sustainable land management. Canadian Journal of Soil Science 75: 407-412. 
ORNL/TM-2004/41

\section{INTERNAL DISTRIBUTION}

1-6. C.T. Garten, Jr., Bldg. 1505 (6038)

7. V.H. Dale, Bldg. 1505 (6036)

8. R.L. Graham, Bldg. 1505 (6036)

9. G.K. Jacobs, Bldg. 1505 (6035)

10. A.W. King, Bldg. 1509 (6335)

11. P.J. Mulholland, Bldg. 1505 (6036)
12-14. ESD Library

15. ORNL Central Research Library

16. ORNL Laboratory Records CRC

17. ORNL Laboratory Records BOSTI

\section{EXTERNAL DISTRIBUTION}

18. T.L. Ashwood, 418 Keota Lane, Loudon, TN 37774

19. H.E. Balbach, U.S. Army Engineer Research and Development Center (ERDC), P.O. Box 9005, Champaign, IL 61826-9005

20. W.D. Goran, U.S. Army Engineer Research and Development Center (ERDC), P.O. Box 9005, Champaign, IL 61826-9005

21. R. Washington-Allen, 14 Windhaven Lane, Oak Ridge, TN 37830

\section{ELECTRONIC NOTIFICATION}

22. Teresa Aden (Teresa.S.Aden@erdc.usace.army.mil)

23. Neil Burns (Burns.Neil@epamail.epa.gov)

24. John Brent (John.Brent@benning.army.mil)

25. Beverly Collins (collins@srel.edu)

26. Roger Dahlman (Roger.Dahlman@science.doe.gov)

27. John Dilustro (dilustro@srel.edu)

28. John Hall (john_hall@TNC.ORG)

29. Robert Holst (robert.holst@osd.mil)

30. Jennifer Jacobs (jjaco@ce.ufl.edu)

31. Louis Kaplan (lakaplan@stroudcenter.org)

32. Katherine Kirkman (kkirkman@jonesctr.org)

33. Rose Kress (kressr@wes.army.mil)

34. Tony Krzysik (krzysika@cableone.net)

35. Joe Prenger (jprenger@ufl.edu)

36. David Price (priced@wes.army.mil)

37. K. Ramesh Reddy (krr@mail.ifas.ufl.edu)

38. Pete Swiderek (swiderekp@benning.army.mil)

39. Hugh Westbury (Hugh.Westbury@Benning.Army.Mil) 